\title{
O MANDADO DE INJUNÇÃO NA ASSEMBLEIA NACIONAL CONSTITUINTE DE 1987-1988
}

\author{
HENRIQue Augusto FigueIREDO FulgÊNCIO ${ }^{\dagger}$ \\ AleXANDRE ARAÚJo COSTA ${ }^{\dagger \dagger}$
}

RESUMO: O presente artigo descreve a introdução do mandado de injunção no ordenamento jurídico brasileiro por meio da análise dos discursos parlamentares ocorridos durante a Assembleia Nacional Constituinte de 1987-1988 e do processamento das propostas que introduziram este instrumento na Constituição em vigor. A partir do levantamento de dados primários constantes das bases de dados da Assembleia Nacional Constituinte, o trabalho apresenta mapeamento do trajeto percorrido pelas propostas que originaram os dispositivos constitucionais relacionados ao mandado de injunção, dentre os quais se destaca o artigo 5⿳亠丷厂, inciso LXXI, da Constituição da República. Por fim, alguns dos aspectos reputados como mais relevantes do processo de criação do instituto em exame são destacados com amparo em fontes secundárias, em que se incluem obras de juristas que participaram, na condição de membro ou assessor, da Assembleia Constituinte. Nessa última etapa, busca-se explicitar dados ou indícios que possam contribuir para a compreensão a respeito da conformação que os constituintes pretenderam conferir ao mandado de injunção.

Palavras-Chave: Constituição de 1988; Assembleia Nacional Constituinte; Inconstitucionalidade por Omissão; Mandado de Injunção; Tradição Liberal-Conservadora.

\footnotetext{
${ }^{\dagger}$ Mestre e Doutorando em Direito pela UnB. Membro da Advocacia-Geral da União.

${ }^{\dagger}$ Professor da Faculdade de Direito da UnB. Mestre e Doutor em Direito pela UnB.
} 
ABSTRACT: This article describes the introduction of the writ of injunction in the Brazilian Legal System, by analyzing the congressional speeches carried out during the National Constitutional Assembly of 1987-1988 and the processing of the motions that introduced said institute to the present Constitution. Through the collection of primary data within the National Constitutional Assembly's Database, the work presents a mapping of the trajectory of the motions that originated the constitutional provisions related to the writ of injunction, among which article 5, item LXXI, of the Constitution deserves mention. Lastly, some of the aspects deemed more relevant to the creative process of the institute in question are highlighted with the aid of secondary sources, such as works from legal scholars who took part in the Constitutional Assembly, as members or consultants. In this last stage, data or evidence shall be detailed in order to contribute to the understanding of the frame that said constituents wished to give to the injunction relief.

KEYWORDS: 1988 Brazilian Constitution; National Constitutional Assembly; Unconstitutionality by Omission; Writ of Injunction; LiberalConservative Tradition. 


\section{SUMÁRIO:}

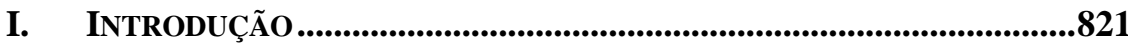

II. MAPEAMENTO DA TRAJETÓRIA DO MANDADO DE INJUNÇÃO

NA ASSEMBLEIA CONSTITUINTE ............................................824

1. Comissão da Soberania e dos Direitos e Garantias

do Homem e da Mulher

1.1. Subcomissão dos Direitos e Garantias Individuais.....827

1.2. Subcomissão de Direitos Políticos, dos Direitos Coletivos e Garantias...............................830

1.3. Reunião das propostas das Subcomissões na Comissão

2. Comissão de Sistematização.....................................................836

3. Plenário da Assembleia Nacional Constituinte.....................847

III. AVAliaÇÃo ACERCa das CARACTERÍSTICAS ATRIBUídaS PELA CONSTITUINTE AO MANDAdO DE INJUNÇÃO ..........................853

IV. CONSIDERAÇÕES FINAIS........................................................................861

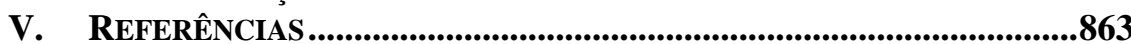

\section{TABLE OF CONTENTS:}

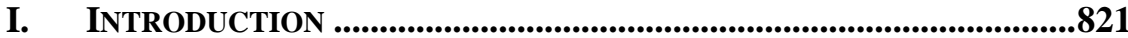

II. MAPPING OF THE WRIT OF INJUNCTION'S TRAJECTORY

IN THE CONSTITUTIONAL ASSEMBLY

1. The Committee for Sovereignty and

Rights and Guarantees of Man and Woman

1.1. The Subcommittee for

Individual Rights and Guarantees...

1.2. The Subcommittee for Political Rights,

Collective Rights and Guarantees....

1.3. The Reunion of the Subcommittees' motions

in the Committee

2. The Systematizing Committee 836

3. Plenary of the National Constitutional Assembly ................847

III. EVALUATION CONCERNING THE CHARACTERISTICS ATTRIBUTED TO THE WRIT OF INJUNCTION BY THE

NATIONAL CONSTITUTIONAL ASSEMBLY.............................................853

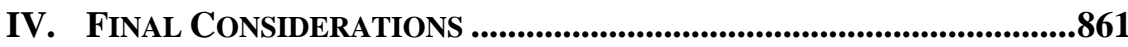

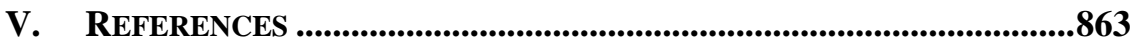




\section{INTRODUÇÃO}

O mandado de injunção (MI) é uma modalidade de ação judicial criada pela Constituição de 1988 (CF/88) para a assegurar a observância das disposições constitucionais de eficácia limitada ${ }^{1}$ que estabelecem direitos e liberdades, bem como prerrogativas inerentes à nacionalidade, à soberania e à cidadania. Trata-se de instrumento especificamente voltado a combater o problema da inconstitucionalidade por omissão estatal no contexto de uma ordem constitucional de caráter dirigente ${ }^{2}$, omissão esta que se configura quando a falta de edição de normas legislativas ou administrativas pelo Estado (autoridades, órgãos ou entidades) impede que as pessoas exerçam direitos previstos constitucionalmente.

Além de encontrar previsão expressa no texto constitucional ${ }^{3}$, o mandado de injunção foi recentemente regulamentado pela Lei 13.300, de 23 de junho de 2016. A edição desse diploma legal após quase 30 anos de sua criação torna especialmente relevante a reconstrução histórica da introdução do mandado de injunção em nossa ordem constitucional, visto que a compreensão do processo legislativo oferece elementos relevantes para a interpretação e aplicação da nova lei e para uma análise acerca dos significados das inovações acarretadas por essa nova regulação.

O presente trabalho é justamente voltado a reconstruir essa história por meio do resgate de eventos ocorridos no âmbito da Assembleia Nacional Constituinte de 1987-1988. A partir da análise de dados primários disponíveis nos sítios eletrônicos da Câmara dos Deputados ${ }^{4} \mathrm{e}$ do Senado Federal ${ }^{5}$, consistentes nos anais e em outros documentos produzidos pela Constituinte, buscou-se mapear o trajeto percorrido pelo mandado de injunção em cada uma das 25 fases do processo constituinte,

${ }^{1}$ SILVA, José Afonso da. Aplicabilidade das Normas Constitucionais. $8^{\underline{a}}$ ed. São Paulo, SP: Malheiros, 2012.

${ }^{2}$ CANOTILHO, José Joaquim Gomes. Constituição Dirigente e Vinculação do Legislador: contributo para a compreensão das normas constitucionais programáticas. Coimbra: Coimbra Editora, 1982.

${ }^{3}$ Artigos 5, inciso LXXI; 102, inciso I, alínea "q", e inciso II, alínea "a"; 105, inciso I, alínea "h"; e 121, § 4º, inciso V, da CF/88.

${ }^{4}$ Disponível em: $<$ http://www2.camara.leg.br/atividadelegislativa/legislacao/Constituicoes Brasileiras/constituicao-cidada/o-processoconstituinte>. Acesso em: 01 de agosto de 2016.

${ }^{5}$ Disponível em: $<$ http://www.senado.gov.br/publicacoes/anais/asp/CT Abertura.asp $>$. Acesso em: 01 de agosto de 2016. 
desde as primeiras propostas no sentido de sua criação até a votação, pelo Plenário, do texto definitivo dos dispositivos relacionados ao instituto.

A pesquisa empírica se concentrou na identificação das várias propostas legislativas sobre o tema, de suas justificativas e dos processos decisórios envolvidos na formulação do texto constitucional acerca do mandado de injunção. A partir desse levantamento de dados, buscou-se (i) identificar as decisões políticas que interferiram na configuração do texto constitucional, (ii) mapear as tensões políticas que se tornam visíveis a partir das contraposições argumentativas narradas nos anais da Constituinte e (iii) identificar as funções que eram atribuídas ao mandado de injunção no contexto da Assembleia Constituinte. Essa análise subsidiou o desenvolvimento de uma narrativa na qual prepondera a dimensão semântica dos discursos, sendo focada na compreensão dos argumentos utilizados para justificar as propostas legislativas e decisões da Constituinte. Não se trata, pois, de uma pretensa reconstrução objetiva de fatos ocorridos ou de um sentido unívoco originário acerca do mandado de injunção, que pudesse ser atribuído a um mítico legislador constituinte. Trata-se do desenvolvimento de uma narrativa que atribui aos debates constituintes um sentido que seja bem articulado com os argumentos efetivamente utilizados pelos atores da época e que, nessa medida, constitua uma interpretação hermeneuticamente adequada dos discursos analisados neste trabalho. ${ }^{6}$

Essa abordagem se justifica pelo fato de que, na literatura sobre mandado de injunção, são comuns ilações sobre os objetivos e as inspirações desta ação, mas elas normalmente não são baseadas em pesquisa primária. ${ }^{7}$ Além disso, essa reconstrução é relevante para avaliar

${ }^{6}$ GADAMER, Hans-Georg. Verdade e método: traços fundamentais de uma

hermenêutica filosófica. Trad. Flávio Paulo Meurer. 3ํeㄹ. ed. Petrópolis, RJ: Vozes, 1999.

${ }^{7}$ É esse o caso, dentre tantos outros, dos trabalhos citados a seguir: ARAÚJO, Luiz

Henrique Diniz. O Mandado de Segurança, o Mandado de Injunção e a efetivação dos

direitos sociais. Revista de Informação Legislativa, Ano 50, n. 199, 2013; GALLO, Luiz

Carlos; FACHIN, Zulmar. O Mandado de Injunção na Jurisprudência do Supremo

Tribunal Federal. Revista Jurídica Cesumar - Mestrado, Vol. 12, 1, 2012; MENDES,

Gilmar Ferreira. O mandado de injunção e a necessidade de sua regulação legislativa.

Revista Jurídica da Presidência, Vol. 13, 100, 2011; RAMOS, Elival da Silva. Mandado de injunção e separação dos Poderes. Cadernos Jurídicos, Ano 16, n. 40, 2015; RAMOS, Paulo Roberto Barbosa; LIMA, Diogo Diniz. Mandado de injunção: origem e perspectivas. Revista de Informação Legislativa, Ano 48, n. 191, 2011;

ROTHENBURG, Walter Claudius. A segunda geração do mandado de injunção.

Revista de Informação Legislativa, Ano 47, n. 188, 2010. 
a eficácia contemporânea desse instrumento processual, uma vez que a pesquisa indica que ele foi concebido para garantir a aplicabilidade de direitos sociais em benefício dos cidadãos em geral, ao passo que a grande maioria das decisões de procedência proferidas pelo Supremo Tribunal Federal (STF) em sede de mandado de injunção se refere, exclusivamente, a questões funcionais de servidores públicos, conforme se verificou em exame preliminar ao conjunto de acórdãos disponíveis no sítio eletrônico desse tribunal.

Considerando-se o elevado quantitativo de dados produzidos pela Assembleia de 1987-1988, os documentos analisados foram objeto de seleção destinada a resgatar as propostas, as emendas, os debates e as decisões dos constituintes relacionados aos temas da conveniência ou não da criação do mandado de injunção e das características normativas que se pretendeu conferir ao instituto. Os acontecimentos retratados não foram selecionados em razão do conteúdo das manifestações dos constituintes: após serem identificadas, em cada fase do processo constituinte, todas as ocorrências dos termos "injunção", "mandado", "omissão", "lacuna" e "falta" nas bases de dados pesquisadas ${ }^{8}$, foram reunidos e resumidos no presente trabalho os registros relativos aos eventos que exerceram, de acordo com a nossa avaliação, maior influência sobre a solução tomada ao final do processo constituinte, bem como as manifestações que apresentaram, de maneira explícita, argumentos favoráveis ou contrários à sua adoção.

O resultado da investigação empreendida está consolidado na próxima seção deste artigo, destinada a apresentar o mapeamento da trajetória das propostas que originaram os dispositivos constitucionais relacionados ao mandado de injunção e, em especial, o artigo $5^{\mathrm{o}}$, inciso LXXI, da Constituição de 1988. A reconstituição do percurso percorrido por tais propostas inicia-se pela referência às primeiras sugestões, que foram apresentadas nos 30 dias subsequentes à promulgação do Regimento Interno da ANC. Passa-se, posteriormente, ao relato dos trabalhos desenvolvidos pelas subcomissões e comissões, bem como pelo Plenário da Constituinte, conferindo-se ênfase aos órgãos da Assembleia que produziram os registros mais relevantes a respeito dos temas pesquisados.

Por fim, empreende-se avaliação tendente a destacar elementos do processo constituinte que contribuem para a compreensão da estrutura que os parlamentares pretenderam atribuir ao mandado de injunção, os quais são referências relevantes para a interpretação e a aplicação do

${ }^{8}$ Disponível em: $<$ http://www6g.senado.gov.br/apem/search $>$. Acesso em: 01 de agosto de 2016.

2 JOURNAL OF INSTITUTIONAL STUDIES 2 (2016) 
instituto em exame e das disposições constantes da Lei 13.300/16. Embora o presente trabalho priorize a utilização de dados primários, esta avaliação é amparada por informações extraídas de fontes secundárias, em que se incluem obras de juristas que participaram, na condição de membro ou assessor, da Assembleia Constituinte.

\section{MAPEAMENTO DA TRAJETÓRIA Do MANDADO DE INJUNÇÃo NA ASSEMbleia CONSTITUINTE}

A Assembleia Nacional Constituinte instalou-se no dia 1\%/2/1987, em observância ao disposto pelo artigo $1^{\circ}$ da Emenda Constitucional 26, de 1985. Inicialmente, seu funcionamento regeu-se pela Resolução 1, de 6/2/1987, até que, em 24/3/1987, o presidente da Constituinte, Ulysses Guimarães (PMDB), promulgou a Resolução 2, que definiu o Regimento Interno da Constituinte. No título IV desta resolução, referente às regras para a elaboração da Constituição, foram previstas, além da Comissão de Sistematização, 8 comissões temáticas, incumbidas de elaborar as normas gerais e as disposições transitórias e finais relativas às matérias de sua competência. Cada uma das 8 comissões temáticas era composta por 3 subcomissões.

O artigo 14, § 2o, do Regimento Interno conferiu aos constituintes o prazo de 30 dias, contados da data de sua promulgação, para o oferecimento de sugestões à elaboração do Projeto de Constituição, as quais seriam encaminhadas às respectivas comissões temáticas. Já no dia 27/3/1987, ou seja, 3 dias após a promulgação do Regimento Interno da Assembleia Constituinte, a primeira sugestão no sentido da criação do mandado de injunção foi apresentada. Trata-se da Sugestão 155, subscrita pelo senador Virgílio Távora (PDS) e por seu filho, o deputado Carlos Virgílio (PDS), que propunham a inclusão, no capítulo relativo aos direitos e garantias constitucionais, de dispositivo com o seguinte teor:

Art. Sempre que se caracterizar a inconstitucionalidade por omissão, conceder-se-á "mandado de injunção", observado o rito processual estabelecido para o mandato de segurança. ${ }^{9}$

${ }^{9}$ BRASIL, ASSEMBLEIA NACIONAL CONSTITUINTE. Diário da Assembleia Nacional Constituinte, Brasília, 29 abr. 1987, Suplemento, p. 99. Disponível em: $<$ http://www2.camara.leg.br/atividadelegislativa/legislacao/Constituicoes Brasileiras/constituicao-cidada/o-processo- 
Ao justificarem essa sugestão de norma, os referidos parlamentares caracterizaram o mandado de injunção como uma garantia destinada a combater a omissão inconstitucional provocada por qualquer dos três Poderes constituídos, configurada pela ausência de norma ou ato cuja edição seja necessária para efetivar direitos subjetivos previstos pela Constituição, especialmente dos direitos sociais. Essa finalidade também foi enfatizada pelo senador Alfredo Campos (PMDB $)^{10}$, que ressaltou o ineditismo e a relevância da proposta de criação do mandado de injunção, que constituiria, a seu ver, o instrumento máximo de expressão da cidadania na democracia brasileira. Ele afirmou expressamente que tal instituto se voltava à proteção não apenas de direitos individuais, mas, especialmente, de direitos sociais, tais como os direitos à saúde, à educação, à habitação, à participação do trabalhador nos lucros da empresa e ao salário mínimo capaz de atender às suas necessidades vitais básicas e às de sua família.

Alfredo Campos também indicou que a referida Sugestão 155 havia sido elaborada pela assessora legislativa Herzeleide Maria Fernandes de Oliveira, que alertara Virgílio Távora para os problemas concernentes à inobservância contumaz dos governantes brasileiros quanto ao disposto pelas normas constitucionais que asseguram direitos sociais. De fato, em artigo científico publicado no final de 1988, quando já havia sido promulgada a Constituição em vigor, Oliveira ${ }^{11}$ esclareceu que a proposta surgira na Assessoria Legislativa do Senado Federal no sentido de proteger, especificamente, o direito subjetivo à educação diante da omissão do Estado em efetivá-lo. Como os "remédios constitucionais" até então existentes no ordenamento brasileiro não foram considerados aptos a tal finalidade, sugeriu-se a criação de instrumento processual que, embora fosse considerado inédito, inspirava-se "[...] nas 'injunctions' inglesas, mais precisamente no 'writ of injunction' americano e na 'inconstitucionalidade por omissão' prevista na Constituição portuguesa

constituinte/sugestoes-dos-constituintes/arquivos/SGCO0101-0200.pdf >. Acesso em: 01 de agosto de 2016.

${ }^{10}$ BRASIL, ASSEMBLEIA NACIONAL CONSTITUINTE. Diário da Assembleia

Nacional Constituinte, Brasília, 24 ago. 1988, p. 29. 1988. Disponível em:

$<$ http://www.senado.leg.br/publicacoes/anais/constituinte/N023.pdf $>$. Acesso em: 01 de agosto de 2016.

${ }^{11}$ OLIVEIRA, Herzeleide Maria Fernandes de. O Mandado de Injunção. Revista de Informação Legislativa, Ano 25, n. 100, 1988. 
(art. 283)."12. Herzeleide Oliveira indica que o mandado de injunção foi concebido para a defesa de um direito social específico, mas que ele acabou sendo estendido para os demais direitos de cunho social e, posteriormente, para a proteção da Constituição como um todo.

A vinculação originalmente existente entre o mandado de injunção e o direito constitucional à educação é confirmada por outra sugestão apresentada à Constituinte por Virgílio Távora e Carlos Virgílio. Na Sugestão 315, os parlamentares propuseram a inclusão da seguinte regra entre as normas reguladoras dos princípios e diretrizes da educação e do ensino no País:

Art. O ensino básico, com oito anos de duração, é obrigatório para todos.

Parágrafo único. $\mathrm{O}$ acesso ao ensino básico é um direito público subjetivo, acionável contra o Poder Público, mediante mandado de injunção. ${ }^{13}$

Propostas semelhantes constaram de outras sugestões feitas em abril de 1987, que defendiam a inclusão, no texto constitucional, de previsão específica da possibilidade de utilização do mandado de injunção para concretizar o direito à educação ou ao ensino ${ }^{14}$. Merece destaque a Sugestão 367/1987, do senador Ruy Bacelar (PMDB), que apresentou dispositivo com teor semelhante ao proposto pela mencionada Sugestão 155 sob a justificativa de que o mandado de injunção seria, certamente, um marco importante na história do direito brasileiro, pois obrigaria o Estado a por em prática previsões constitucionais que, a exemplo dos direitos à saúde e à educação, seriam capazes de melhorar a vida do cidadão. Essa convergência sugere que vários parlamentares foram efetivamente convencidos pela argumentação da Assessoria Parlamentar, tanto que incorporaram a suas propostas a mesma denominação (mandado de injunção) e objetivos bastante similares.

12 OLIVEIRA, Herzeleide Maria Fernandes de. O Mandado de Injunção. Revista de Informação Legislativa, Ano 25, n. 100, 1988, p. 60.

${ }^{13}$ BRASIL, ASSEMBLEIA NACIONAL CONSTITUINTE. Diário da Assembleia

Nacional Constituinte, Brasília, 29 abr. 1987, Suplemento, p. 141. Disponível em:

$<$ http://www2.camara.leg.br/atividade-

legislativa/legislacao/Constituicoes Brasileiras/constituicao-cidada/o-processoconstituinte/sugestoes-dos-constituintes/arquivos/sgco0301-0400>. Acesso em: 01 de agosto de 2016.

14 Sugestões 370, do senador Jutahy Magalhães (PMDB); 502, do senador Mário Maia (PMDB); 734, do senador Louremberg Nunes Rocha (PMDB); e 740, do senador Nilvado Machado (PFL). 
Essas formulações indicam que, em um primeiro momento, o mandado de injunção não foi pensado como forma de sobrepujar a omissão normativa, mas a omissão do Estado na formulação e execução de políticas públicas adequadas para a efetivação de direitos sociais. Esse objetivo ficou ainda mais claro na Sugestão 3.666/1987, apresentada cerca de um mês depois das propostas mencionadas, em que o senador Humberto Lucena (PMDB) propôs a instituição de um mandado de garantia social, que possuiria finalidades semelhantes às atribuídas ao mandado de injunção, mas seria especificamente vinculado, inclusive pela denominação, à garantia sugerida e aos direitos sociais.

\section{Comissão da Soberania e dos Direitos e Garantias do Homem e da Mulher}

As referidas sugestões, formuladas entre maio e abril de 1987, foram encaminhadas à análise das comissões temáticas pertinentes às matérias nelas versadas. Na Comissão da Soberania e dos Direitos e Garantias do Homem e da Mulher, a inconstitucionalidade por omissão foi tratada em duas subcomissões que tinham como temática sobreposta a questão das garantias: a Subcomissão dos Direitos e Garantias Individuais tratou do mandado de injunção como um dos direitos constantes do que veio a ser o art. 5 da CF/88, enquanto a Subcomissão dos Direitos Políticos, dos Direitos Coletivos e Garantias tratou da ação direta de inconstitucionalidade por omissão (ADO) como instrumento voltado a suprir lacunas que limitassem o pleno exercício das prerrogativas inerentes à soberania popular e dos direitos e garantias previstos na Constituição. Tais subcomissões foram instaladas em 7/4/1987, quando se iniciou o prazo de 30 dias para que o relator de cada uma delas apresentasse relatório fundamentado com anteprojeto acerca da matéria, nos termos do artigo 17 da Resolução 2/1987.

\subsection{Subcomissão dos Direitos e Garantias Individuais}

Nesta Subcomissão, as sugestões dos constituintes foram consolidadas em um anteprojeto apresentado em 11/5/1987 pelo relator Darcy Pozza (PDS), que atribuía especial relevância à criação do mandado de injunção, caracterizado como instrumento de defesa dos interesses do cidadão. $\mathrm{O}$ relator ressaltou que havia acolhido as citadas Sugestões 367 e 3.666, que propunham respectivamente a instituição do mandado de injunção e do mandado de garantia social, e apresentou um 
anteprojeto que contou com apenas 1 artigo, composto pelo caput, por 33 incisos e 35 parágrafos. Neste artigo, que é o gérmen do atual artigo $5^{\circ}$ da Constituição Federal, o tema da omissão inconstitucional foi tratado em dois pontos:

Art. (...) São direitos e garantias individuais:

$[\ldots]$

IV - a liberdade particular; ninguém será obrigado a fazer ou a deixar de fazer alguma coisa, senão em virtude de lei; na falta ou omissão da lei, o juiz decidirá o caso de modo a atingir os fins da norma constitucional; verificando-se a inexistência ou omissão da lei, o Tribunal proporá ao Poder competente a edição de norma que venha a suprir a falta;

[...]

§ 35 Os direitos e garantias constantes desta Constituição têm aplicação imediata. Conceder-se-á mandado de injunção, para garantir direito nela assegurado, não aplicado em razão da ausência de norma regulamentadora, podendo ser requerido em qualquer Juízo ou Tribunal. ${ }^{15}$

Essa redação já mostra uma redução do mandado de injunção à omissão normativa, e não a omissões materiais do Estado. Além disso, denota a divisão, que veio a se confirmar no texto final, entre estratégias para suprir a omissão legislativa em abstrato (nas quais os tribunais poderiam reconhecer a omissão e determinar a edição de normas faltantes) e entre estratégias para garantir a aplicabilidade concreta de direitos (em que decisões judiciais poderiam suprir a omissão para o caso concreto).

Na sequência, abriu-se prazo para a apresentação de emendas ao anteprojeto do relator pelos demais membros da subcomissão. Acerca dos dispositivos relacionados à omissão inconstitucional, destacam-se a Emenda 238, do deputado João da Mata (PFL), que sugeria suprimir o § 35 do anteprojeto e, por conseguinte, retirar de seu texto o mandado de injunção e a previsão de aplicabilidade imediata dos direitos e garantias constitucionais, sob o fundamento de que se tratava de inovações incompatíveis com o direito brasileiro; e a Emenda 297, do deputado Michel Temer (PMDB), que pretendia deixar claro, no texto do mencionado $\S 35$, o direito de qualquer cidadão a obter, do Poder Judiciário, o suprimento da omissão inconstitucional por meio do

${ }^{15}$ BRASIL, ASSEMBLEIA NACIONAL CONSTITUINTE. Relatório e Anteprojeto [do Relator da Subcomissão dos Direitos e Garantias Individuais], p. 7-15. Disponível em: $<$ http://www.camara.gov.br/internet/constituicao20anos/DocumentosAvulsos/vol78.pdf>. Acesso em: 01 de agosto de 2016. 
mandado de injunção.

Ainda sobre o § 35 do anteprojeto, o senador Virgílio Távora propôs, em consonância com a Sugestão 155 que apresentara anteriormente, a inclusão de previsão no sentido de que o mandado de injunção seguiria o mesmo rito processual do mandado de segurança. Essa previsão foi incorporada ao substitutivo do relator, apresentado em 23/5/1987, que também contemplou referência à necessidade de observância das regras de competência da lei processual. O objetivo, segundo Darcy Pozza, foi evitar a ocorrência de tumulto na aplicação do mandado de injunção, o que poderia ocorrer caso qualquer cidadão pudesse pleitear a ordem a qualquer juízo ou tribunal.

O substitutivo do relator foi aprovado pela unanimidade dos constituintes presentes na vigésima sexta reunião da Subcomissão dos Direitos e Garantias Individuais, realizada em 23/5/1987, ressalvados as emendas e os destaques apresentados.

Posteriormente, em decorrência da aprovação de destaque do constituinte José Fernandes (PDT) à Emenda 108, de sua própria autoria, restou suprimida do artigo único do substitutivo a expressão "na falta ou omissão da lei, o juiz decidirá o caso de modo a atingir os fins de norma constitucional; verificando-se a inexistência ou omissão da lei, o Tribunal proporá ao Poder competente a edição de norma que venha a suprir a falta". Ao justificar referida emenda e o respectivo destaque, José Fernandes sustentou que as previsões suprimidas contrariavam a tradição constitucional brasileira, pois permitir que o juiz decida de acordo com os fins da norma constitucional corresponderia a conferir margem de arbítrio ao membro do Poder Judiciário, ao passo que a atribuição de recomendar a edição da norma faltante ao Poder competente seria incompatível com a inércia do Judiciário e com o direito do Legislativo a legislar. Sendo assim, o Anteprojeto da Subcomissão dos Direitos e Garantias Individuais, em seu texto final, encerrou os seguintes dispositivos:

Art. (...) São direitos e garantias individuais:

$[\ldots]$

IV - a liberdade individual; ninguém será obrigado a fazer ou a deixar de fazer alguma coisa, senão em virtude de lei;

[...]

$\S 36$ - Os direitos e garantias constantes desta Constituição têm aplicação imediata.

$\S 37$ - Conceder-se-á mandado de injunção, observado o rito processual estabelecido para o mandado de segurança, a fim de garantir direito assegurado nesta Constituição, não aplicado em razão da ausência de norma regulamentadora, podendo ser requerido em qualquer Juízo ou Tribunal, 
observadas as regras de competência da Lei processual. ${ }^{16}$

O anteprojeto da subcomissão foi, então, encaminhado à Comissão da Soberania e dos Direitos e Garantias do Homem e da Mulher, que o recebeu em 26/5/1987. Na ocasião, Darcy Pozza destacou, novamente, o mandado de injunção como sendo um dos principais avanços do texto apresentado.

\subsection{Subcomissão de Direitos Políticos, dos Direitos Coletivos e Garantias}

A Subcomissão dos Direitos Políticos, dos Direitos Coletivos e Garantias funcionou sob a relatoria de Lysâneas Maciel (PDT), cujo anteprojeto, apresentado em 14/5/1987, dedicou diversos dispositivos ao tema da inconstitucionalidade por omissão. Embora não tenha contemplado o instituto do mandado de injunção, o referido anteprojeto previa a criação da ação direta de inconstitucionalidade por omissão, a ser processada e julgada por uma corte constitucional denominada de Tribunal de Garantias Constitucionais, que teria competência, inclusive, para suprir a lacuna de normas necessárias ao pleno exercício das prerrogativas inerentes à soberania popular e dos direitos e garantias previstos na Constituição, aos quais atribuía aplicabilidade imediata. Esse anteprojeto também permitia que qualquer interessado requeresse judicialmente a aplicação direta do direito constitucional pendente de regulamentação. Tais previsões estavam contidas nos artigos $3^{\circ}$, inciso IV; $6^{\circ}$, caput e $\S 1^{\circ}$, alínea "b"; $7^{\circ}$, caput e parágrafo único; $8^{\circ}$, $\S 1^{\circ}$; e 38 , caput, do anteprojeto mencionado, em cuja apresentação o relator destacou a relevância do instituto da inconstitucionalidade por omissão para as questões relacionadas aos direitos à saúde, à educação e ao saneamento básico.

$\mathrm{Na}$ fase de apresentação de emendas ao anteprojeto do relator, o senador Humberto Lucena reiterou proposta que fizera por meio da já citada Sugestão 3.666, defendendo a inclusão do mandado de garantia social no elenco de medidas assecuratórias da aplicabilidade das normas constitucionais que preveem direitos sociais, tais como os direitos à educação, à saúde, à segurança e à habitação. A sugestão foi incorporada

${ }^{16}$ BRASIL, ASSEMBLEIA NACIONAL CONSTITUINTE. Anteprojeto [da

Subcomissão dos Direitos e Garantias Individuais], p. 02-15. Disponível em: $<$ http://www.camara.gov.br/internet/constituicao20anos/DocumentosAvulsos/vol81.pdf>. Acesso em: 01 de agosto de 2016. 
pelo relator em seu substitutivo, o qual, em 23/5/1987, foi aprovado com 13 votos favoráveis e 1 contrário, ressalvados os destaques. Em tal ocasião, Lysâneas Maciel salientou a contribuição de Humberto Lucena e afirmou que uma das grandes preocupações da subcomissão por ele relatada era garantir a eficácia das normas constitucionais, tendo destacado, novamente, os direitos sociais à saúde e à educação.

De acordo com o anteprojeto, o mandado de garantia social seria cabível nos casos de inexistência ou omissão de norma, ato jurisdicional ou ato administrativo necessário ao pleno exercício das prerrogativas inerentes à soberania popular e dos direitos e garantias constitucionais. Nessa medida, não se tratava apenas de instrumento voltado a suprir omissões legislativas, mas também omissões administrativas que inviabilizassem o exercício de direitos constitucionais, a ser julgado por um tribunal especificamente voltado a examinar questões relativas às garantias constitucionais.

\subsection{Reunião das propostas das Subcomissões na Comissão}

Em 26/5/1987, os anteprojetos das subcomissões mencionadas foram recebidos pela Comissão da Soberania e dos Direitos e Garantias do Homem e da Mulher, cujo relator era o senador José Paulo Bisol (PSDB), abrindo-se prazo para a apresentação de emendas. Na sequência, em atendimento ao artigo 18 da Resolução 2/1987, coube ao relator emitir parecer sobre os anteprojetos das subcomissões e sobre as emendas a estes oferecidas na própria Comissão, concluindo-o com a apresentação de um substitutivo, que veio a ser apresentado em 6/1/1987 e que conferiu à omissão inconstitucional o tratamento descrito no quadro comparativo que se segue. 


\begin{tabular}{|c|c|}
\hline Substitutivo do Relator ${ }^{17}$ & $\begin{array}{c}\text { Anteproieto da Subcomissão dos Direitos } \\
\text { Políticos, dos Direitos Coletivos e } \\
\text { Garantias }^{18}\end{array}$ \\
\hline $\begin{array}{l}\text { Art. } 29[\ldots] \\
\S 1^{\mathrm{o}}-\text { As normas que definem esses direitos, } \\
\text { liberdades e prerrogativas têm eficácia } \\
\text { imediata. }^{19}\end{array}$ & $\begin{array}{l}\text { Art. } 5^{\mathrm{o}} \text { - As normas constitucionais } \\
\text { asseguradoras dos direitos individuais, } \\
\text { coletivos ou difusos têm aplicabilidade plena } \\
\text { e imediata. } \\
\text { [...] } \\
\text { Art. } 7^{\mathrm{o}} \text { - As prerrogativas individuais } \\
\text { inerentes ao exercício da soberania do povo e } \\
\text { os direitos e garantias constitucionais têm } \\
\text { aplicabilidade plena e imediata, e são } \\
\text { protegidas pela ação direta de } \\
\text { inconstitucionalidade e pelo mandado de } \\
\text { garantia social. }\end{array}$ \\
\hline $\begin{array}{l}\S 2^{o} \text { - Na falta de leis, decretos ou atos } \\
\text { complementares necessários à aplicação } \\
\text { dessas normas, o iuiz ou o Tribunal } \\
\text { competente para o iulgamento, suprirá a } \\
\text { lacuna, à luz dos princípios fundamentais da } \\
\text { Constituicão e das Declaracões } \\
\text { Internacionais de Direitos de que o País seia } \\
\text { signatário, recorrendo de ofício, sem efeito } \\
\text { suspensivo, ao Tribunal de Garantia dos } \\
\text { Direitos Constitucionais. } \\
\S 3^{o} \text { - Os suprimentos normativos deduzidos } \\
\text { em última instância, na forma do parágrafo }\end{array}$ & $\begin{array}{l}\text { Artigo } 8^{o} \text { - A declaracão de } \\
\text { inconstitucionalidade de norma e ato } \\
\text { iurisdicional ou administrativo é } \\
\text { desconstitutiva; a concessão de garantia } \\
\text { social por inexistência ou omissão de norma } \\
\text { confere ao Tribunal Constitucional a } \\
\text { competência para suprir a lacuna, e a norma, } \\
\text { assim produzida, terá vigência até que a } \\
\text { instituição ou órgão competente a revogue } \\
\text { por substituicão, seia qual for a diferenca de } \\
\text { hierarquia; e a por inexistência ou omissão }\end{array}$ \\
\hline
\end{tabular}

${ }^{17}$ BRASIL, ASSEMBLEIA NACIONAL CONSTITUINTE. Parecer e Substitutivo [do

Relator da Comissão da Soberania e dos Direitos e Garantias do Homem e da

Mulher], p. 8-10. Disponível em:

$<$ http://www.camara.gov.br/internet/constituicao20anos/DocumentosAvulsos/vol68.pdf $>$. Acesso em: 01 de agosto de 2016.

${ }^{18}$ BRASIL, ASSEMBLEIA NACIONAL CONSTITUINTE. Anteprojeto [da

Subcomissão dos Direitos Políticos, dos Direitos Coletivos e Garantias], p. 03-06.

Disponível em:

$<$ http://www.camara.gov.br/internet/constituicao20anos/DocumentosAvulsos/vol-

77.pdf >. Acesso em: 01 de agosto de 2016.

${ }^{19} \mathrm{O}$ Anteprojeto da Subcomissão de Direitos e Garantias Individuais previa disposição semelhante: “Art. [...] § 36 - Os direitos e garantias constantes desta Constituição têm aplicação imediata." BRASIL, ASSEMBLEIA NACIONAL CONSTITUINTE.

Anteprojeto [da Subcomissão dos Direitos e Garantias Individuais], p. 02-15.

Disponível em:

$<$ http://www.camara.gov.br/internet/constituicao20anos/DocumentosAvulsos/vol81.pdf $>$. Acesso em: 01 de agosto de 2016. 
anterior, terão vigência de lei até que o órgão competente os revogue por substituição.

de ato iurisdicional ou administrativo obriga a instituição ou órgão competente a editá-lo no prazo que a sentenca consignar, importando a desobediência em perda da investidura.

Art. $7^{\circ}$ - As prerrogativas individuais inerentes ao exercício da soberania do povo e os direitos e garantias constitucionais têm aplicabilidade plena e imediata, e são protegidas pela ação direta de inconstitucionalidade e pelo mandado de garantia social.

Art. $3^{\circ}$ - O povo exerce a Soberania:

Art. 30 - [...] IV - pelo mandado de injunção; prerrogativas inerentes à nacionalidade, à soberania do povo e à cidadania, é garantida: $[\ldots]$

Art. $3^{\circ}$ [... $]$ VII - pelo mandado de garantia social por inexistência ou omissão de norma, atos jurisdicional ou administrativo;

Art. $3^{0}\lceil$... $\rceil$ VI - pela ação direta de

Art. 30 - 「...† VIII - pela ação de declaração de inconstitucionalidade.

inconstitucionalidade por norma, atos jurisdicional ou administrativo;

Art. 30 - 「...1 Parágrafo único - Oualquer Iuízo ou Tribunal, observadas as regras da lei processual, é competente para conhecer, processar e julgar as garantias constitucionais. [...]

Art. 34 - Conceder-se-á mandado de injunção, observado o rito processual do mandado de seguranca, sempre que a falta de norma regulamentadora torne inviável o exercício dos direitos e liberdades constitucionais e das prerrogativas inerentes à nacionalidade, à soberania do povo e à cidadania. $[\ldots]^{20}$

${ }^{20}$ O Anteprojeto da Subcomissão de Direitos e Garantias Individuais previa disposições semelhantes: “Art [...] § 37 - Conceder-se-á mandado de injunção, observado o rito processual estabelecido para o mandado de segurança, a fim de garantir direito assegurado nesta Constituição, não aplicado em razão da ausência de norma regulamentadora, podendo ser requerido em qualquer Juízo ou Tribunal, observadas as regras de competência da Lei processual." BRASIL, ASSEMBLEIA NACIONAL CONSTITUINTE. Anteprojeto [da Subcomissão dos Direitos e Garantias Individuais], p. 02-15. Disponível em: 


\begin{tabular}{|c|c|}
\hline $\begin{array}{l}\text { Art. } 38 \text { - Cabe acão direta de declaracão de } \\
\text { inconstitucionalidade nos casos de: }[. . .]\end{array}$ & $\begin{array}{l}\text { Art. } 7^{\mathfrak{O}}\left\lceil\ldots 1 \S 1^{\circ} \text { - Cabe a acão direta de }\right. \\
\text { inconstitucionalidade nos casos de: }\end{array}$ \\
\hline $\begin{array}{l}\text { II - inexistência ou omissão de normas de } \\
\text { qualquer grau e origem, ou de atos } \\
\text { administrativos ou iurisdicionais, sem os } \\
\text { quais é inviável o pleno exercício dos direitos } \\
\text { e das liberdades constitucionais e das } \\
\text { prerrogativas inerentes à nacionalidade, à } \\
\text { soberania do povo e à cidadania. } \\
\text { Parágrafo único - Nos casos de } \\
\text { inconstitucionalidade por inexistência ou } \\
\text { omissão de atos de administracão, se o } \\
\text { Estado demonstrar comprovadamente a } \\
\text { impossibilidade da prestacão por falta ou } \\
\text { insuficiência de recursos, o Iuízo ou Tribunal } \\
\text { a declarará para o efeito de exigir, em prazo } \\
\text { que consignar, um programa de erradicação } \\
\text { da impossibilidade, ou, existindo o } \\
\text { programa, para o efeito de firmar prioridade } \\
\text { e fixar os prazos limites das etapas de } \\
\text { execução. [...] }\end{array}$ & 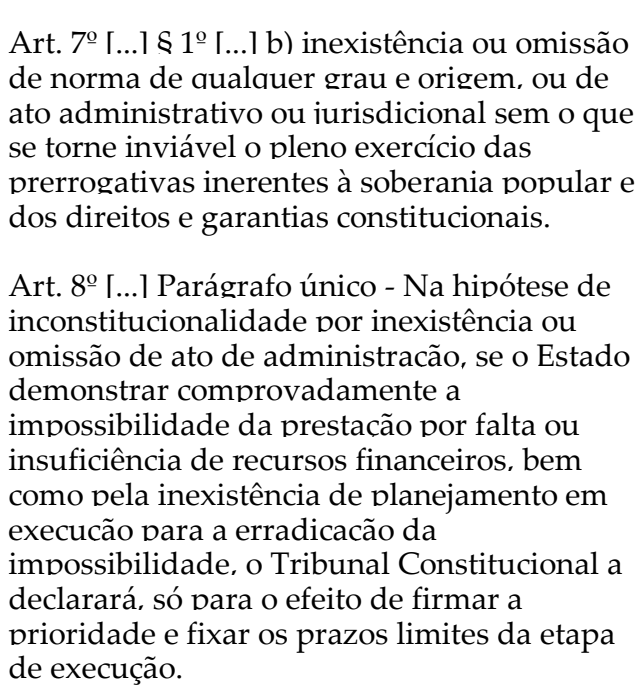 \\
\hline $\begin{array}{l}\text { Art. } 39 \text { - As ações previstas no art. } 30 \text { são } \\
\text { gratuitas, respondendo o Estado pelos } \\
\text { honorários advocatícios quando o autor for } \\
\text { entidade beneficente ou associativa de } \\
\text { âmbito comunitário, ou pessoa física de } \\
\text { renda familiar inferior a dez salários } \\
\text { mínimos. [...] }\end{array}$ & \\
\hline $\begin{array}{l}\text { Art. } 41 \text { - É criado o Tribunal de Garantias dos } \\
\text { Direitos Constitucionais, da Soberania do } \\
\text { Povo, da Nacionalidade e da Cidadania. }\end{array}$ & $\begin{array}{l}\text { Art. 9o - É criado o Tribunal de Garantias } \\
\text { Constitucionais da soberania do povo e dos } \\
\text { direitos constitucionalizados. }\end{array}$ \\
\hline $\begin{array}{l}\text { § } 1^{\circ} \text { - Compete ao Tribunal de Garantias } \\
\text { Constitucionais apreciar e iulgar em última } \\
\text { instância, os recursos interpostos de } \\
\text { despachos decisórios e sentencas prolatados } \\
\text { nos autos das ações previstas no art. } 30, \\
\text { aiuizadas em defesa dos direitos e liberdades } \\
\text { individuais, coletivos e políticos, e das } \\
\text { prerrogativas inerentes à nacionalidade, à } \\
\text { soberania do povo e a cidadania. [...] }\end{array}$ & $\begin{array}{l}\S 1^{\circ} \text { - Compete ao Tribunal de Garantias } \\
\text { Constitucionais apreciar e julgar em única } \\
\text { instância a acão direta de } \\
\text { inconstitucionalidade e o mandado de } \\
\text { garantia social por norma, acão ou omissão, } \\
\text { que inviabilizem o pleno exercício das } \\
\text { prerrogativas inerentes à soberania popular e } \\
\text { dos direitos fundamentais da pessoa } \\
\text { humana, sejam eles individuais ou coletivos, }\end{array}$ \\
\hline
\end{tabular}

$<$ http://www.camara.gov.br/internet/constituicao20anos/DocumentosAvulsos/vol81.pdf $>$. Acesso em: 01 de agosto de 2016. 


\begin{tabular}{|c|c|}
\hline & previsto nesta Constituição. \\
\hline $\begin{array}{l}\text { Art. } 48 \text { - As formas de suprir a falta de leis } \\
\text { complementares, adotadas pela Constituição, } \\
\text { não serão aplicáveis ao disposto no art. 5으, } \\
\text { inciso IV, alínea "e". }\end{array}$ & \\
\hline $\begin{array}{l}\S 1^{\circ} \text { - A lacuna permanecendo depois de seis } \\
\text { meses da promulgação da Constituição, } \\
\text { qualquer cidadão, associação, partido } \\
\text { político, sindicato ou entidade civil poderá } \\
\text { promover mandado de injunção para o efeito } \\
\text { de obrigar o Congresso a legislar sobre o } \\
\text { assunto no prazo que a sentença consignar. }\end{array}$ & \\
\hline $\begin{array}{l}\S 2^{\circ} \text { - Ultrapassado o prazo sem atendimento, } \\
\text { o Tribunal de Garantias Constitucionais } \\
\text { suprirá a lacuna. }\end{array}$ & \\
\hline
\end{tabular}

Especificamente quanto ao instituto em exame, nota-se que o substitutivo do senador Paulo Bisol optou pela designação adotada pela Subcomissão dos Direitos e Garantias Individuais, denominando-o de Mandado de Injunção. A proposta proveniente desta subcomissão prevaleceu, ainda, em relação a dois pontos relevantes:

a) competência difusa para julgar o mandado de injunção, que foi atribuída a qualquer juízo ou tribunal, e não ao Tribunal de Garantias Constitucionais, em caráter exclusivo (art. 30, parágrafo único); e

b) limitação do objeto do mandado de injunção aos casos de falta de norma, de modo a excluir as hipóteses de ausência de atos jurisdicionais ou administrativos destituídos de caráter normativo (art. 34).

O substitutivo foi emendado na Comissão, mas essas modificações não causaram alterações substanciais nos artigos mencionados. Dentre as emendas apresentadas nessa fase, destacam-se a 162 e a 164, ambas de autoria do deputado José Carlos Grecco (PMDB), que sugeria a supressão do mandado de injunção sob a justificativa de que o instituto seria incompatível com o princípio da separação de Poderes. No entendimento do deputado, a generalização da possibilidade, conferida ao Poder 
Judiciário, de suprir diretamente as lacunas legislativas seria bastante temerária, pois poderia ocasionar, até mesmo, situações de ingovernabilidade em qualquer país, razão pela qual a decisão proferida em mandado de injunção deveria se limitar a expedir mera recomendação aos órgãos omissos. As propostas, no entanto, foram rejeitadas pelo relator da comissão, que as considerou inadequadas às finalidades do seu substitutivo.

Afora a supressão do artigo 48, que versava sobre o cabimento do mandado de injunção em hipótese específica, as previsões constantes do substitutivo do relator não sofreram alterações posteriores, tendo sido reproduzidas no anteprojeto da comissão, que foi aprovado no dia 12/6/1987.

\section{Comissão de Sistematização}

Todos os anteprojetos das comissões temáticas foram encaminhados à Comissão de Sistematização, à qual competia compatibilizar as matérias aprovadas e elaborar um texto unificado (art. 19, § 1을 da Resolução 2/1987). A partir dos trabalhos fornecidos pelas comissóes temáticas, o relator Bernardo Cabral (PMDB), elaborou o Anteprojeto de Constituição, que promoveu poucas (mas relevantes) alterações nas previsões constantes do anteprojeto elaborado pela Comissão da Soberania e dos Direitos e Garantias do Homem e da Mulher.

A principal mudança foi a exclusão da proposta de criação de um Tribunal de Garantias voltado exclusivamente a julgar questões constitucionais. Todas as referências a essa nova Corte foram excluídas dos dispositivos mencionados anteriormente e as menções feitas a ela foram substituídas por referências ao STF.

Cabe ressaltar que houve, na Constituinte, um debate acirrado acerca da conveniência de manter a competência constitucional do STF ou se era mais adequado criar uma Corte Constitucional. Segundo Andrei Koerner e Lígia Barros de Freitas ${ }^{21}$, a instituição de um Tribunal Constitucional ou de um Tribunal de Garantias Constitucionais, competente, exclusivamente, para julgar questões constitucionais e composto por ministros temporários, escolhidos pelo Congresso Nacional ou pelos três Poderes estatais, foi defendida como necessária em razão da ampliação

${ }^{21}$ KOERNER, Andrei; FREITAS, Lígia Barros de. O Supremo na Constituinte e a Constituinte no Supremo. Lua Nova, No. 88, 2013. Disponível em:

$<$ http://www.scielo.br/pdf/ln/n88/a06n88.pdf $>$. Acesso em: 01 de agosto de 2016. 
dos direitos e garantias que seriam assegurados pela nova Constituição, a exemplo do mandado de injunção. Além de ter sido apreciada pelas subcomissões e comissão mencionadas anteriormente, referida proposta também foi formulada no âmbito da Subcomissão do Poder Judiciário e do Ministério Público, cujo relator, o deputado Plínio de Arruda Sampaio (PT), sugeriu a criação de um Tribunal Constitucional no anteprojeto que apresentara.

Tais propostas contrariavam a pretensão dos ministros do STF de preservar a existência do tribunal na ordem a ser instaurada, o que já havia sido manifestado pelos membros da Corte em 30/6/1986, quando encaminharam exposição de motivos contendo sugestões à Comissão Provisória de Estudos Constitucionais a respeito da organização e das atribuições do Poder Judiciário. ${ }^{22}$ A decisão tomada no âmbito da Comissão de Sistematização e que prevaleceu até o fim do processo constituinte no sentido da manutenção do STF é considerada por Koerner e Freitas ${ }^{23}$ como uma vitória obtida pela aliança bem-sucedida entre ministros do STF e constituintes conservadores.

Além disso, o Anteprojeto de Constituição incorporou dispositivos provenientes de outras comissões que também diziam respeito ao tema da inconstitucionalidade por omissão. Dos Anteprojetos da Comissão da Organização dos Poderes e Sistema de Governo e da Comissão da Família, da Educação, Cultura e Esportes, da Ciência e Tecnologia e da Comunicação, Bernardo Cabral extraiu, respectivamente, os seguintes artigos:

Art. 207 - São partes legítimas para propor ação de inconstitucionalidade: [...] $\S 2^{2}$ - Declarada a inconstitucionalidade por omissão, de medida para tornar efetiva norma constitucional, será assinado prazo ao órgão do poder competente, para a adoção das providências necessárias, sob pena de responsabilidade e suprimento pelo Supremo Tribunal Federal.

$\S 3^{\mathrm{o}}$ - Decorrido o prazo aludido no parágrafo anterior sem que seja sanada a omissão, poderá o Supremo Tribunal Federal editar resolução, a qual, com força de lei, vigerá supletivamente. [...]

22 BRASIL, SUPREMO TRIBUNAL FEDERAL. Exposição de Motivos: inovações sugeridas pelo Supremo Tribunal Federal. Diário da Justiça, Brasília, ano 61, n. 131, p. 12289-12295, 14 jul. 1986. Disponível em:

<http://www.stf.jus.br/arquivo/biblioteca/PastaSTF/Curiosidades/1986 jul 14.pdf $>$. Acesso em: 01 de agosto de 2016.

${ }^{23}$ KOERNER, Andrei; FREITAS, Lígia Barros de. O Supremo na Constituinte e a Constituinte no Supremo. Lua Nova, No. 88, 2013. Disponível em:

$<$ http://www.scielo.br/pdf/ln/n88/a06n88.pdf $>$. Acesso em: 01 de agosto de 2016. 
Art. 379 - O dever do Estado com o ensino público efetivar-se-á mediante a garantia de: $[\ldots]$

$\S 1^{\mathrm{o}}$ - O acesso ao ensino obrigatório e gratuito é direito público subjetivo, acionável contra o Estado mediante mandado de injunção. ${ }^{24}$

O artigo 379, § 1으, do Anteprojeto de Constituição possui teor bastante semelhante ao da já mencionada Sugestão 315, apresentada ainda em 2/4/1987 pelos constituintes Virgílio Távora e Carlos Virgílio. Por sua vez, o artigo 207, $\S \S 2^{\mathrm{o}}$ e $3^{\mathrm{o}}$, ao tratar da ação de inconstitucionalidade por omissão, conferia ao Supremo Tribunal Federal competência para, inclusive, suprir a ausência de norma decorrente da inércia do órgão omisso, à semelhança do que fora previsto pelo Anteprojeto da Comissão da Soberania e dos Direitos e Garantias do Homem e da Mulher.

De acordo com o artigo 19 do Regimento Interno, ao Anteprojeto de Constituição poderiam ser apresentadas emendas destinadas, exclusivamente, à adequação de seu texto aos anteprojetos oferecidos pelas comissões temáticas. Assim, as emendas veiculadas nessa fase que buscavam a supressão do instituto sequer foram conhecidas, por serem consideradas incompatíveis com os anteprojetos das comissões temáticas. Esse foi o caso, por exemplo, das emendas 1.417, 3.146 e 5.462, que propunham a supressão do mandado de injunção do texto do anteprojeto do relator Bernardo Cabral. Tais emendas foram oferecidas, respectivamente, pelo deputado José Egreja (PTB), que afirmava pretender a retirada de matéria destituída de caráter constitucional do texto do anteprojeto, e pelos deputados José Santana de Vasconcellos (PFL) e Mendonça de Morais (PMDB), que consideravam a criação do mandado de injunção como perigosa e inoportuna por possibilitar interferências nocivas entre os Poderes. As Emendas 3.441, 3.764 e 4.367, apresentadas, respectivamente, pelos deputados Arnaldo Prieto (PFL), Francisco Benjamim (PFL) e Ricardo Fiuza (PFL), sugeriam a supressão do $\S 1^{\circ}$ do artigo 379 do Anteprojeto de Constituição, sob as justificativas de que o mandado de injunção não deveria servir para a garantia de situações individuais, de que a concessão do direito ao ensino tornaria desnecessária a previsão de cabimento do mandado de injunção e de que a utilização desse instituto em favor dos diversos estudantes causaria entupimento nos canais judiciários.

Oportunizou-se, também, a apresentação de emendas populares e de

${ }^{24}$ BRASIL, ASSEMBLEIA NACIONAL CONSTITUINTE. Anteprojeto de Constituição [da Comissão de Sistematização], p. 43, 26 jun. 1987. Disponível em:

$<$ http://www.camara.gov.br/internet/constituicao20anos/DocumentosAvulsos/vol219.pdf $>$. Acesso em: 01 de agosto de 2016. 
emendas oferecidas pelos constituintes ao Projeto de Constituição. Nessa etapa, ocorreram novas tentativas de supressão do mandado de injunção, bem como de modificação de sua denominação. A supressão do instituto foi proposta, por exemplo, por meio das Emendas n. 9.454, 13.682, 15.698 e 16.562, apresentadas, respectivamente, pelos deputados Naphtali Alves De Souza (PMDB), Oswaldo Almeida (PL), Basílio Villani (PMDB) e Antônio Carlos Konder Reis (PDS). Naphtali Alves De Souza e Oswaldo Almeida sustentaram que o dispositivo que previa o mandado de injunção conteria, na verdade, matéria de lei ordinária, ao passo que o Projeto de Constituição deveria ser sintético. Por sua vez, Antônio Carlos Konder Reis e Basílio Villani afirmaram que a criação do mandado de injunção e da ação direta de inconstitucionalidade por omissão seria incompatível com as previsões contidas no artigo 31 do Projeto de Constituição, que dispunha o seguinte:

Art. 31 - Os direitos, liberdades e prerrogativas previstos nesta Constituição não excluem outros inerentes aos princípios fundamentais da Nação, ou constantes de Declarações Internacionais assinadas pelo Pais.

$\S 1^{\mathrm{o}}$ - As normas que definem esses direitos, liberdades e prerrogativas têm eficácia imediata.

$\S 2^{\mathrm{o}}$ - Na falta de leis, decretos ou atos complementares necessários à aplicação dessas normas, o juiz ou o Tribunal competente para o julgamento suprirá a lacuna, à luz dos princípios fundamentais da Constituição e das Declarações Internacionais de Direitos de que o País seja signatário, recorrendo de ofício, sem efeito suspensivo, ao Supremo Tribunal Federal.

$\S 3^{\mathrm{o}}$ - Os suprimentos normativos deduzidos em última instância, na forma do parágrafo anterior, terão vigência de lei até que o órgão competente os revogue por substituição.

Todas as propostas de supressão do mandado de injunção e de alteração de sua denominação foram rejeitadas. Quanto ao suposto conflito entre, de um lado, o mandado de injunção e a ação direta por omissão, e, de outro, o artigo 31 do Projeto de Constituição, o relator Bernardo Cabral optou pela eliminação dos parágrafos deste dispositivo, atendendo, desse modo, a diversas emendas que propunham sua supressão, tais como as Emendas 530 e 5.518, de Inocêncio Oliveira (PFL), as Emendas 3.620 e 8.649, de Paes Landim (PFL), a Emenda 7.789, de Paulo Pimentel (PFL), a Emenda 8.038, de Maluly Netto (PFL), e a Emenda 12.913, de João Rezek (PMDB).

Merece destaque, ainda, a Emenda 7.788, de Paulo Pimentel (PFL), que sugeria a supressão do dispositivo que autorizava qualquer juízo ou tribunal a conhecer, processar e julgar as garantias constitucionais elencadas no artigo 32 do Projeto de Constituição, dentre as quais 
figurava o mandado de injunção. De acordo com o autor da proposta, referido dispositivo havia se tornado desnecessário diante da previsão, no texto do projeto, do princípio da inafastabilidade da tutela jurisdicional. O relator Bernardo Cabral retirou o dispositivo em questão do texto do projeto, considerando a emenda como prejudicada.

Assim, ressalvada a supressão do dispositivo mencionado, todas as previsões relativas ao Mandado de Injunção que constavam do Anteprojeto da Comissão da Soberania e dos Direitos e Garantias do Homem e da Mulher, bem como do Anteprojeto e do Projeto de Constituição apresentados por Bernardo Cabral foram mantidos, sem alterações relevantes, no Primeiro Substitutivo do Relator da Comissão de Sistematização, de 26/8/1987, cujo texto compreendia os seguintes dispositivos:

Art. 19 - A inviolabilidade absoluta dos direitos e liberdades constitucionais e das prerrogativas inerentes à nacionalidade, à soberania do povo e à cidadania é garantida: [...]

IV - pelo mandado de injunção; [...]

Art. 23 - Conceder-se-á mandado de injunção, observado o rito processual do mandado de segurança, sempre que a falta de norma regulamentadora torne inviável o exercício dos direitos e liberdades constitucionais e das prerrogativas inerentes à nacionalidade, à soberania do povo e à cidadania. [...]

Art. 26 - As ações previstas no artigo 19 são gratuitas quando o autor for entidade beneficente ou associativa de âmbito comunitário, ou pessoa física de renda familiar inferior a dez salários mínimos, respondendo o Estado pelos honorários advocatícios. [...]

Art. 275 - [...]

Parágrafo único - O acesso ao ensino obrigatório e gratuito é direito público subjetivo, acionável contra o Estado mediante mandato de injunção. 25

Na sequência, novas emendas tendentes a suprimir o mandado de injunção ou a alterar a denominação do instituto foram oferecidas por diversos constituintes. Quanto à designação do instituto, o senador Lavoisier Maia, autor da Emenda 25.864, sugeriu, uma vez mais, o emprego da denominação de "mandato de concretização", ao passo que

${ }^{25}$ BRASIL, ASSEMBLEIA NACIONAL CONSTITUINTE. Primeiro Substitutivo do Relator e Parecer [da Comissão de Sistematização ao Projeto de Constituição], p. 2145, 26 ago. 1987. Disponível em:

$<$ http://www.camara.gov.br/internet/constituicao20anos/DocumentosAvulsos/vol235.pdf>. Acesso em: 01 de agosto de 2016. 
o deputado Siqueira Campos (PDC) propôs, por meio das Emendas 24.264 e 24.270, a utilização das expressões "ação cominatória" e "mandato cominatório". Por sua vez, as Emendas 30.087 e 30.088, do deputado Doreto Campanari (PMDB), propunham a substituição de "mandado de injunção" por "mandato cominatório", e a Emenda 24.218, do deputado Aloysio Chaves (PFL), defendia o uso da expressão "mandado de integração".

Observaram-se, ademais, propostas de alteração da denominação que vinham acompanhadas de sugestões de mudança dos efeitos a serem produzidos pelo mandado de injunção. Aloysio Chaves, que havia sugerido o nome "mandado de integração", propôs, por meio da Emenda 24.219, que o instituto fosse chamado de "mandato de integração", o qual, por ensejar a prolação de decisões de natureza normativa, não deveria contemplar a possibilidade de deferimento de medida liminar, visto que o exercício da função legislativa dependeria de longo processo de discussão e exame técnico. Por sua vez, o deputado José Egreja, que já tentara suprimir o mandado de injunção em mais de uma ocasião, propôs que o instituto passasse a se denominar "ação declaratória". Mais do que simples tentativas de modificar sua designação, as Emendas 29.346, 29.349 e 32.184, de José Egreja, voltavam-se a transformar o mandado de injunção em instrumento revestido de eficácia meramente declaratória, sob a justificativa de que a alteração sugerida se compatibilizava com a tradição da sociedade brasileira e com a tripartição de Poderes.

Mais uma vez, o relator da Comissão de Sistematização rejeitou as propostas de supressão e de alteração do nome do instituto em exame, bem como não acatou as emendas que pretendiam limitar sua eficácia. Diversamente, no entanto, do que se observara na fase anterior, Bernardo Cabral acolheu emendas que propiciaram modificações relevantes, em relação ao texto do seu Primeiro Substitutivo. Dentre as propostas aprovadas pelo relator, a Emenda 34.644, do deputado Adolfo Oliveira (PL), provocou o deslocamento dos artigos 19, inciso IV, 23 e 26 do Primeiro Substitutivo, cujo conteúdo passou a constar de parágrafos do artigo 5ํㅜ do Segundo Substitutivo. Veja-se: 


\begin{tabular}{|c|c|}
\hline Primeiro Substitutivo & Segundo Substitutivo ${ }^{26}$ \\
\hline $\begin{array}{l}\text { Art. } 19 \text { - A inviolabilidade absoluta dos } \\
\text { direitos e liberdades constitucionais e das } \\
\text { prerrogativas inerentes à nacionalidade, à } \\
\text { soberania do povo e à cidadania é } \\
\text { garantida: [...] } \\
\text { IV - pelo mandado de injunção; [...] } \\
\text { Art. } 23 \text { - Conceder-se-á mandado de } \\
\text { injunção, observado o rito processual do } \\
\text { mandado de segurança, sempre que a falta } \\
\text { de norma regulamentadora torne inviável o } \\
\text { exercício dos direitos e liberdades } \\
\text { constitucionais e das prerrogativas } \\
\text { inerentes à nacionalidade, à soberania do } \\
\text { povo e à cidadania. }\end{array}$ & $\begin{array}{l}\text { Art. } 5^{o} \text { - Todos são iguais perante a lei, sem } \\
\text { distinção de qualquer natureza. } \\
\text { [...] } \\
\S 47 \text { - Conceder-se-á mandado de injunção, } \\
\text { observado o rito processual previsto em lei } \\
\text { complementar, sempre que a falta de } \\
\text { norma regulamentadora torne inviável o } \\
\text { exercício das liberdades constitucionais e } \\
\text { das prerrogativas inerentes à } \\
\text { nacionalidade, à soberania do povo e à } \\
\text { cidadania. }\end{array}$ \\
\hline $\begin{array}{l}\text { Art. } 26 \text { - As ações previstas no artigo } 19 \text { são } \\
\text { gratuitas quando o autor for entidade } \\
\text { beneficente ou associativa de âmbito } \\
\text { comunitário, ou pessoa física de renda } \\
\text { familiar inferior a dez salários mínimos, } \\
\text { respondendo o Estado pelos honorários } \\
\text { advocatícios. [...] }\end{array}$ & $\begin{array}{l}\text { Art. } 5^{\circ}[\ldots] \\
\S 52 \text { - As ações previstas nos } \S \S 44 \text { a } 48 \text { são } \\
\text { gratuitas quando o autor for entidade } \\
\text { beneficente ou associações de caráter } \\
\text { comunitário, ou pessoa física, quando } \\
\text { comprovada a insuficiência de recursos, } \\
\text { respondendo o Estado pelos honorários } \\
\text { advocatícios. }\end{array}$ \\
\hline $\begin{array}{l}\text { Art. } 275 \text { - โ... } \\
\text { Parágrafo único - O acesso ao ensino } \\
\text { obrigatório e gratuito é direito público } \\
\text { subietivo, acionável contra o Estado } \\
\text { mediante mandato de injunção. }\end{array}$ & \\
\hline
\end{tabular}

Como se nota, o relator Bernardo Cabral optou pela retirada do termo "direitos" do texto do artigo 19, inciso IV, do Primeiro Substitutivo, de modo que o $\S 47$ do artigo $5^{\circ}$ do Segundo Substitutivo somente conteve referência às prerrogativas e liberdades constitucionais. Este dispositivo também deixou de mencionar o rito processual do mandado de segurança, passando a submeter o mandado de injunção ao rito

${ }^{26}$ BRASIL, ASSEMBLEIA NACIONAL CONSTITUINTE. Segundo Substitutivo do Relator [da Comissão de Sistematização ao Projeto de Constituição], p. 27-30, set. 1987. Disponível em:

$<$ http://www.camara.gov.br/internet/constituicao20anos/DocumentosAvulsos/vol242.pdf $>$. Acesso em: 01 de agosto de 2016. 
processual previsto em lei complementar. Esta modificação derivou da aprovação da Emenda 29.893, do deputado Manoel Moreira (PMDB), que considerava mais adequado deixar a regulamentação da matéria ao legislador do que estender, no próprio texto constitucional, o rito do mandado de segurança ao mandado de injunção, cuja aplicação poderia "[...] causar inúmeros problemas, inclusive injustiças e excessiva pressa na efetivação de tal instrumento."27. A justificativa apresentada por Manoel Moreira estava em consonância com o entendimento do relator, que já havia manifestado, em diversas ocasiões, a preocupação de não detalhar, no texto da Constituição, as características normativas do mandado de injunção, as quais, em seu entendimento, deveriam ser objeto de disciplina pela legislação infraconstitucional.

Por sua vez, a parte final do artigo 275, parágrafo único, do Primeiro Substitutivo, que previa a utilização do mandado de injunção como instrumento de acesso ao ensino obrigatório e gratuito foi suprimida. A ausência dessa previsão no texto do Segundo Substitutivo atendeu às sugestões feitas pelo senador Roberto Campos (PMDB) e pelo deputado Octávio Elísio (PMDB) por meio, respectivamente, das Emendas 23.631 e 33.721. O deputado Octávio Elísio havia defendido, em fase anterior, a supressão do próprio instituto do mandado de injunção, ao passo que o senador Roberto Campos já sustentara a inadequação da possibilidade de impetração de mandado de injunção por todo e qualquer aluno, independentemente da verificação de sua aptidão para absorver o ensino, o que, a seu ver, causaria o bloqueio dos canais judiciários.

Por fim, o relator acatou sugestões constantes das Emendas 28.659 e 28.660, do deputado Alfredo Campos, e da Emenda 32.225, do deputado Nelson Jobim (PMDB), para incluir referência expressa ao mandado de injunção nos dispositivos que enunciavam os processos a serem julgados pelo Supremo Tribunal Federal, pelo Superior Tribunal de Justiça, pelos Tribunais Regionais Federais e Eleitorais, e pelos juízes federais. A nova redação deixava claro que a competência para julgar determinado mandado de injunção não seria comum a todo e qualquer juízo, mas deveria observar os critérios de distribuição de competência entre os órgãos do Judiciário. Assim, quanto ao instituto em exame, o Segundo Substitutivo contemplou, além dos já transcritos $\S \S 47$ e 52 do artigo 5으, as previsões que se seguem:

${ }^{27}$ BRASIL, ASSEMBLEIA NACIONAL CONSTITUINTE. Projeto de Constituição: Emendas Oferecidas em Plenário ao Substitutivo do Relator, Vol. III (Emendas 27037 a 31127), p. 2203. Disponível em:

$<$ http://www.camara.gov.br/internet/constituicao20anos/DocumentosAvulsos/vol238.pdf>. Acesso em: 01 de agosto de 2016. 
Art. 121 - Compete ao Supremo Tribunal Federal, precipuamente, a guarda da Constituição, cabendo-lhe:

I - processar e julgar, originariamente: [...]

d) o "habeas corpus", sendo paciente qualquer das pessoas referidas nas alíneas anteriores; o mandado de segurança, o "habeas data" e o mandado de injunção contra atos do Presidente da República, do Primeiro-Ministro, das Mesas da Câmara Federal e do Senado da República, do Tribunal de Contas da União, do Procurador-Geral da República, do Superior Tribunal de Justiça e do próprio Supremo Tribunal Federal; [...]

II - julgar, em recurso ordinário: [...]

b) o mandado de segurança, o "habeas data" e o mandado de injunção decididos em única instância pelos Tribunais Superiores, se denegatória a decisão; [...]

Art. 124 - Compete ao Superior Tribunal de Justiça:

I - processar e julgar, originariamente: [...]

b) os mandados de segurança, os "habeas data" e os mandados de injunção contra ato de Ministro de Estado ou do próprio Tribunal; [...]

Art. 127 - Compete aos Tribunais Regionais Federais:

I - processar e julgar originariamente: [...]

c) os mandados de segurança, os "habeas data" e os mandados de injunção contra ato do próprio tribunal ou de juiz federal; [...]

Art. 128 - Aos juízes federais compete processar e julgar: [...]

VIII - os mandados de segurança, os "habeas data" e os mandados de injunção contra ato de autoridade federal, excetuados os casos de competência dos tribunais federais; [...]

Art. 139 - Das decisões dos Tribunais Regionais Eleitorais somente caberá recurso, quando: [...]

V - denegarem "habeas corpus", mandado de segurança, "habeas data" e mandado de injunção. ${ }^{28}$

Em 21/9/1987, o deputado Aluízio Campos (PMDB), no exercício da presidência da Comissão de Sistematização, esclareceu que, em razão de entendimento entre as lideranças, seriam admissíveis requerimentos de destaque do Projeto de Constituição, do Primeiro e do Segundo Substitutivos, bem como de emendas apresentadas ao Projeto e ao

${ }^{28}$ BRASIL, ASSEMBLEIA NACIONAL CONSTITUINTE. Segundo Substitutivo do Relator [da Comissão de Sistematização ao Projeto de Constituição], p. 54-58, set. 1987. Disponível em:

$<$ http://www.camara.gov.br/internet/constituicao20anos/DocumentosAvulsos/vol242.pdf $>$. Acesso em: 01 de agosto de 2016. 
Primeiro Substitutivo. Caso fossem aprovados por maioria absoluta no Plenário da Comissão de Sistematização, esses destaques seriam incorporados ao texto final. Em 26/9 e em 29/10, respectivamente, os títulos II e IV do Segundo Substitutivo, que continham os dispositivos pertinentes ao mandado de injunção, foram aprovados, com a ressalva dos destaques. Passa-se, a seguir, ao relato dos destaques relevantes para o tema em exame que foram apreciados nessa fase.

Saliente-se, inicialmente, o Destaque 4.700, do deputado Euclides Scalco (PMDB), que sugeria substituir, no $\S 47$ do artigo $5^{\circ}$ do Segundo Substitutivo, a expressão "observado o rito processual previsto em lei complementar" pela frase "observada a lei". Em defesa do destaque, o deputado Nelson Jobim asseverou que, por ser um instituto novo, a definição das características materiais e processuais do mandado de injunção dependeriam de regulamentação específica mediante lei, a qual não deveria se limitar, portanto, aos aspectos procedimentais do instituto. Além disso, diante da necessidade de sua edição para a aplicação do mandado de injunção, seria adequado evitar que tal diploma legal fosse submetido à reserva de lei complementar. Contando com a anuência do relator Bernardo Cabral, o destaque foi aprovado em votação realizada no dia 3/10/1987.

O deputado Aluízio Campos, a seu turno, propôs que a gratuidade prevista no $\S 52$ do artigo $5^{\mathbf{0}}$ do Segundo Substitutivo somente fosse aplicável aos institutos do habeas corpus e do habeas data, cuja impetração seria gratuita independentemente de comprovação de insuficiência de recursos. A referência ao mandado de injunção seria, então, retirada desse dispositivo, o que não obstaria, no entanto, que os comprovadamente carentes de recursos gozassem de assistência judiciária gratuita. O relator também apoiou o destaque, que foi aprovado, no dia 5/10/1987, pela unanimidade dos 79 constituintes votantes.

Na mesma data, aprovou-se o Destaque 3.860 à Emenda 27.361, ambos de autoria do deputado Gastone Righi (PTB), que sugeria a inclusão, no texto do projeto, de dispositivo que reconhecesse aplicação imediata aos direitos e garantias fundamentais. Segundo Gastone Righi, o povo estava a esperar uma constituição que, ao menos em relação a esses direitos e garantias, não ficasse na dependência de leis posteriores, o que postergaria sua incidência.

Com esses destaques incorporados em seu texto, os títulos II e IV do Segundo Substitutivo tiveram suas redações finais aprovadas em 28/10/1987 e em 7/11/1987, respectivamente. Os trabalhos da Comissão de Sistematização originaram, então, o Projeto de Constituição A, apresentado em 24/11/1987, que se destinava à discussão e votação em primeiro turno pelo Plenário da Assembleia Constituinte e cujo texto 


\section{compreendeu os seguintes dispositivos:}

Art. $6^{\circ}$ Todos são iguais perante a lei, sem distinção de qualquer natureza. [...] $\S 51$. Conceder-se-á mandado de injunção, na forma da lei, sempre que a falta de norma regulamentadora torne inviável o exercício das liberdades constitucionais e das prerrogativas inerentes à nacionalidade, à soberania do povo e à cidadania. [...]

$\S 60$. As normas definidoras dos direitos e garantias fundamentais têm aplicação imediata.

Art. 126 - Compete ao Supremo Tribunal Federal, precipuamente, a guarda da Constituição, cabendo-lhe:

I - processar e julgar, originariamente: [...]

d) o "habeas corpus", sendo paciente qualquer das pessoas referidas nas alíneas anteriores; o mandado de segurança, o "habeas data" e o mandado de injunção contra atos do Presidente da República, do Primeiro-Ministro, das Mesas da Câmara dos Deputados e do Senado Federal, do Tribunal de Contas da União, do Procurador-Geral da República, do Superior Tribunal de Justiça e do próprio Supremo Tribunal Federal; [...]

II - julgar, em recurso ordinário:

a) o "habeas corpus", o mandado de segurança, o "habeas data" e o mandado de injunção decididos em única instância pelos Tribunais Superiores, se denegatória a decisão; [...]

Art. 129 - Compete ao Superior Tribunal de Justiça:

I - processar e julgar, originariamente: [...]

b) os mandados de segurança, os "habeas data" e os mandados de injunção contra ato de Ministro de Estado ou do próprio Tribunal; [...]

Art. 132 - Compete aos Tribunais Regionais Federais:

I - processar e julgar, originariamente: [...]

c) os mandados de segurança, os "habeas data" e os mandados de injunção contra ato do próprio tribunal ou de Juiz Federal; [...]

Art. 133 - Aos juízes federais compete processar e julgar: [...]

VIII - os mandados de segurança, os "habeas data" e os mandados de injunção contra ato de autoridade federal, excetuados os casos de competência dos tribunais federais; [...]

Art. 145 - Das decisões dos Tribunais Regionais Eleitorais somente caberá recurso, quando: [...]

V - denegarem "habeas corpus", mandado de segurança, "habeas data" ou mandado de injunção. 29

${ }^{29}$ BRASIL, ASSEMBLEIA NACIONAL CONSTITUINTE. Projeto de Constituição (A)

[da Comissão de Sistematização], p. 4-9. Disponível em: 
Como se nota, o Projeto de Constituição A reproduziu as regras de competência relativas ao mandado de injunção que já constavam do Segundo Substitutivo. Em relação ao texto deste substitutivo, as únicas alterações verificadas encontram-se nos mencionados $\$ \S 51$ e 60 do artigo 6 o , bem como no artigo 126, inciso I, alínea " $\mathrm{d}$ ", do Projeto de Constituição A, que substituiu por "Mesas da Câmara dos Deputados e do Senado Federal" a expressão "Mesas da Câmara Federal e do Senado da República", a qual constava do artigo 121, inciso I, alínea "d", do Segundo Substitutivo.

\section{Plenário da Assembleia Nacional Constituinte}

Os momentos finais dos trabalhos desenvolvidos pela Comissão de Sistematização, que culminaram com a apresentação do Projeto $A$, e a transição para a fase de discussão e votação, em primeiro turno, desse projeto pelo Plenário, corresponderam a um período de crise para a Assembleia Nacional Constituinte. De 18/11/1987 a 28/1/1988, a Constituinte interrompeu os trabalhos de elaboração constitucional e dedicou-se à realização de mudanças regimentais. Esse período crítico foi marcado pelo surgimento do "Centrão" 30 , grupo liberal-conservador de constituintes que se notabilizou por provocar a aprovação da Resolução 3 , de 5/1/1988, que introduziu uma série de modificações no Regimento Interno da ANC. ${ }^{31}$

Composto, em sua maioria, por constituintes posicionados políticoideologicamente do centro à direita, a formação desse grupo consistiu em reação ao acolhimento, pela Comissão de Sistematização, de propostas tidas como progressistas. De acordo com Luziano Pereira Mendes de Lima $^{32}$, os integrantes do Centrão argumentavam que o Regimento Interno, ao impedir a participação da maioria dos congressistas na Comissão de Sistematização e limitar o objeto das emendas apresentadas

$<$ http://www.camara.gov.br/internet/constituicao20anos/DocumentosAvulsos/vol251.pdf $>$. Acesso em: 01 de agosto de 2016.

${ }^{30}$ LIMA, Luziano Pereira Mendes de. A atuação da esquerda no processo constituinte: 1986-1988. Brasília, DF: Edições Câmara, 2009.

${ }^{31}$ CENTRO consegue 314 assinaturas para mudar regimento. Folha de São Paulo, São Paulo, p. A9, 11 nov. 1987. Disponível em:

$<$ http://www2.senado.leg.br/bdsf/item/id/152808>. Acesso em: 01 de agosto de 2016.

32 LIMA, Luziano Pereira Mendes de. A atuação da esquerda no processo constituinte: 1986-1988. Brasília, DF: Edições Câmara, 2009. 
ao Projeto de Constituição a um único dispositivo, teria ensejado situação em que "[...] uma minoria de esquerda radical estava conduzindo a Constituinte e erigindo um Estado inviável de esquerda, por conceder um conjunto de direitos sociais absolutamente impraticáveis" ${ }^{33}$. Esse quadro foi modificado em decorrência da edição da mencionada Resolução 3/1988, que autorizou à maioria absoluta dos membros da Constituinte a apresentação de substitutivos a títulos, capítulos, seções e subseções do Projeto de Constituição, bem como condicionou a manutenção dos dispositivos provenientes da Comissão de Sistematização à aprovação da maioria absoluta dos membros da Constituinte ${ }^{34}$.

Essa alteração possibilitou, por exemplo, a apresentação da Emenda Substitutiva 2.038, de autoria atribuída ao Centrão e subscrita por 291 constituintes, que tinha por objeto quatro capítulos do Projeto $A$ referentes aos direitos e liberdades fundamentais. Em 1ㅇ/2/1988, a primeira parte da emenda (referente ao Capítulo I) foi aprovada em Plenário, ressalvados os destaques. No que toca especificamente ao mandado de injunção, essa emenda limitou-se a suprimir a expressão "do povo", que qualificava o substantivo "soberania". Porém, a sistemática da inconstitucionalidade por omissão foi severamente modificada pela exclusão do dispositivo que previa a aplicação imediata dos direitos e garantias fundamentais (art. $6^{\circ}$, $\S 60$, do Projeto A).

Além da proposta do Centrão, merecem destaque outras duas emendas apresentadas em Plenário relativamente ao $\S 51$ do artigo $6^{\circ}$ do Projeto A: as Emendas 722 e 1.513, propostas, respectivamente, pelos senadores Louremberg Nunes Rocha (PMDB) e Fernando Henrique Cardoso (PMDB), que entendiam necessária a inclusão dos direitos constitucionais no objeto do mandado de injunção. Segundo Fernando Henrique Cardoso, sua sugestão visava a restabelecer a amplitude atribuída ao mandado de injunção em suas formulações iniciais, a qual havia sido restringida no projeto da Comissão de Sistematização. Já Louremberg Nunes Rocha citou o direito à educação para sustentar que a proteção dos direitos constitucionais, e não das prerrogativas, é que constituía a finalidade do mandado de injunção.

Embora tenha sido rejeitada pelo relator Bernardo Cabral, a Emenda 1.513 foi objeto do Destaque 1.503, também de autoria do senador

33 OLIVEIRA, Mauro Márcio. Fontes de informações sobre a Assembléia Nacional Constituinte de 1987: quais são, onde buscá-las e como usá-las. Brasília, DF:

Subsecretaria de Edições Técnicas do Senado Federal, 1993.

34 OLIVEIRA, Mauro Márcio. Fontes de informações sobre a Assembléia Nacional

Constituinte de 1987: quais são, onde buscá-las e como usá-las. Brasília, DF:

Subsecretaria de Edições Técnicas do Senado Federal, 1993.

2 JOURNAL OF INSTITUTIONAL STUDIES 2 (2016) 
Fernando Henrique Cardoso. Esse destaque foi fundido com outros dois (Destaque 1.250, de Max Rosenmann e Jovanni Masini, e Destaque 1.523, de Aloysio Teixeira, todos deputados do PMDB), resultando em uma emenda aglutinativa que propunha a substituição do $\S 51$ do $\operatorname{artigo} 6^{0}$ do Projeto A pelo seguinte texto:

$\S$ Conceder-se-á mandado de injunção sempre que a falta de norma regulamentadora torne inviável o exercício dos direitos e liberdades constitucionais e das prerrogativas inerentes à nacionalidade à soberania e à cidadania. ${ }^{35}$

Ao sustentar a proposta por ocasião de sua votação em Plenário, o deputado Jovanni Masini asseverou que se tratava “[...] de restaurar a integridade, a beleza e a pureza de uma das mais belas e mais importantes criações deste processo constitucional: o mandado de injunção." ${ }^{36}$. Importa ressaltar que, além de incluir referência aos direitos constitucionais, essa proposição retirava do texto a expressão "na forma da lei", constante do Projeto A (art. 6으 $§ 51$ ), que condicionava a aplicabilidade do próprio mandado de injunção à definição legal de suas características materiais e processuais.

Submetida à votação no dia 10/2/1988, a proposição foi aprovada, em primeiro turno, com 424 votos favoráveis e 4 abstenções. O texto então aprovado prevaleceu até o fim do processo constituinte, tendo superado posteriores tentativas de restrição.

Já em relação à autoaplicabilidade dos direitos e garantias constitucionais, que era prevista no Projeto A (art. 6⿳⺈, $\S$ 60) mas foi suprimida por iniciativa do Centrão (Emenda Substitutiva 2.038), foram apresentados os Destaques 532, 1.439 e 1.506, pelos constituintes Alfredo Campos (PMDB), Gastone Righi (PTB) e José Costa (PMDB), que pretendiam o retorno do dispositivo excluído, tendo essa proposta sido aprovada em 11/2/1988.

Finalizada a votação em primeiro turno do Projeto $\mathrm{A}$, o relator Bernardo Cabral apresentou, em 5/7/1988, o Projeto de Constituição B

35 BRASIL, ASSEMBLEIA NACIONAL CONSTITUINTE. Diário da Assembleia

Nacional Constituinte, Brasília, 11 fev. 1988, p. 510. Disponível em:

$<$ http://www.senado.leg.br/publicacoes/anais/constituinte/N012.pdf $>$. Acesso em: 01

de agosto de 2016.

36 BRASIL, ASSEMBLEIA NACIONAL CONSTITUINTE. Diário da Assembleia

Nacional Constituinte, Brasília, 11 fev. 1988, p. 510. Disponível em:

$<$ http://www.senado.leg.br/publicacoes/anais/constituinte/N012.pdf $>$. Acesso em: 01

de agosto de 2016.

2 JOURNAL OF INSTITUTIONAL STUDIES 2 (2016) 
(Projeto B), destinado à apreciação pelo Plenário da Constituinte em segundo turno. No que toca ao mandado de injunção, os dispositivos do Projeto A foram repetidos no Projeto B, com exceção do artigo 6o, § 51, que foi substituído pelo artigo 5o, LXXII do Projeto B, com a seguinte redação: "conceder-se-á mandado de injunção sempre que a falta de norma regulamentadora torne inviável o exercício dos direitos e liberdades constitucionais e das prerrogativas inerentes à nacionalidade, à soberania e à cidadania" ${ }^{\prime 37}$. A única modificação adicional verificada consistiu na supressão da referência ao Primeiro-Ministro dentre as autoridades que teriam foro originário no STF para responder a mandado de injunção impetrado contra omissão de sua responsabilidade, em decorrência da opção feita pelo sistema de governo presidencialista.

Embora a redação do artigo 5o, inciso LXXII, do Projeto B tenha derivado de proposta que, em razão de acordo firmado entre as lideranças, restou aprovada com 424 votos favoráveis e nenhum contrário, não se pode afirmar que havia consenso na Constituinte a respeito da relevância e da estrutura desse novo instrumento processual. Tanto é assim que a oposição ao mandado de injunção voltou a ser aguda no segundo turno de discussão e votação do projeto, etapa em que foram novamente apresentadas diversas emendas pela supressão ou pela limitação do objeto e dos efeitos do instituto em exame. O senador João Castelo (PDS), por exemplo, ofereceu a Emenda 444, que veiculava proposta de supressão do inciso LXXII do artigo $5^{\circ}$ do Projeto B. Por sua vez, os deputados Afif Domingos (PL) e Annibal Barcellos (PFL) sugeriram, por meio das Emendas 1.024 e 1.253, a retirada da expressão "dos direitos" do texto do dispositivo referido. Ambos manifestaram preocupação com a amplitude que se estava conferindo ao objeto do mandado de injunção, o que permitiria ao Poder Judiciário legislar em um grande número de ações sobre direitos sociais, tais como os direitos à educação, saúde, lazer e previdência.

Também nessa fase do processo constituinte, o deputado Bonifácio de Andrada (PDS) propôs, mediante a Emenda 1.403, a supressão da expressão "a falta de", do inciso LXXII do artigo $5^{\circ}$ do Projeto B. Embora não tenha sugerido sua eliminação do texto do projeto, Bonifácio de Andrada pretendia retirar do mandado de injunção, justamente, a característica que o tornava relevante e lhe conferia o caráter de novidade, qual seja, sua destinação ao controle da omissão inconstitucional. De

${ }^{37}$ BRASIL, ASSEMBLEIA NACIONAL CONSTITUINTE. Projeto de Constituição: redação para o segundo turno de discussão e votação, p. 18. Disponível em: $<$ http://www.camara.gov.br/internet/constituicao20anos/DocumentosAvulsos/vol-299sup01.pdf $>$. Acesso em: 01 de agosto de 2016. 
acordo com sua proposta, essa função de controle jurisdicional deveria ser desempenhada, exclusivamente, pela ADO, instrumento que também já havia sido bastante enfraquecido em decorrência do acolhimento de proposta do próprio Bonifácio de Andrada. Este deputado foi um dos líderes do Centrão e exerceu papel decisivo na limitação da eficácia da $\mathrm{ADO}$ ao propor a redação que reduzia essa ação a um processo voltado a declarar a existência da lacuna verificada e a cientificar o órgão responsável pela edição da norma faltante $\left(\mathrm{CF} / 88\right.$, art. 103, $\left.\S 2^{\circ}\right)$. Assim, além de limitar consideravelmente os efeitos atribuídos à $\mathrm{ADO}$, este constituinte procurou esvaziar o instituto do mandado de injunção. $\mathrm{O}$ relator Bernardo Cabral, no entanto, proferiu parecer contrário a tais propostas, argumentando que o mandado de injunção correspondia a uma das mais significativas inovações constantes do texto constitucional em elaboração, razão pela qual não se justificava o acatamento de emendas que sugeriam sua eliminação ou a restrição de seu alcance.

As Emendas 444, 1.024, 1.253 e 1.403 constituíram os objetos, respectivamente, dos Destaques 1.550, de José Egreja, 1.392, de Afif Domingos, 1.259, de Annibal Barcellos, e 957, de Bonifácio de Andrada. Posta em discussão a matéria no dia 9/8/1988, o deputado José Egreja, após afirmar que o mandado de injunção havia sido objeto de polêmica desde o início dos trabalhos da ANC, defendeu sua supressão. Em sentido diverso, Nelson Jobim aduziu que se tratava de um instituto extraordinário e moderno, o qual permitiria aos jurisdicionados postular, individualmente, a aplicação de seus direitos constitucionais, de modo a ensejar sua concretização independentemente do processo legislativo. Para Jobim, a manutenção desse instituto seria necessária para a honra da Assembleia Constituinte. A criação do mandado de injunção também foi defendida, em tal ocasião, pelo relator Bernardo Cabral, que o considerou como um dos maiores avanços propiciados pela Constituinte ao povo brasileiro, e pelo deputado Roberto Freire (PCB), segundo o qual quase todas as lideranças estavam apelando pela manutenção dessa grande conquista no texto constitucional. Diante disso, os destaques foram retirados.

Dos dispositivos constantes do Projeto B que versavam sobre o mandado de injunção, as únicas modificações observadas derivaram do acolhimento das Emendas 1.842 e 1.843, ambas do deputado Maurício Nasser (PMDB), que aprimoravam a definição das competências para julgar essa ação, mas não modificavam qualquer elemento mais sensível. Considerando que o mandado de injunção teria por objeto condutas omissivas, e não comissivas, o deputado sugeriu que a competência dos tribunais para julgá-lo fosse prevista em dispositivos específicos, de forma apartada das previsões pertinentes ao habeas corpus, mandado de segurança e habeas data. Além disso, Maurício Nasser propôs que a 
competência do Superior Tribunal de Justiça fosse ampliada para abranger os mandados de injunção impetrados em face de qualquer órgão, entidade ou autoridade federal, excetuados os casos de competência do Supremo Tribunal Federal, da Justiça Militar, da Justiça Eleitoral e da Justiça do Trabalho. Ambas as emendas foram objetos de destaques aprovados pelo Plenário da Constituinte em 25/8/1988.

Ao final do segundo turno de discussão e votação, o Projeto de Constituição C (Projeto C) foi apresentado, em 15/9/1988, com os seguintes dispositivos:

Art. $4^{\circ}[\ldots]$

LXXI - conceder-se-á mandado de injunção sempre que a falta de norma regulamentadora torne inviável o exercício dos direitos e liberdades constitucionais e das prerrogativas inerentes à nacionalidade, à soberania e à cidadania; $[\ldots]$

$\S 1^{\text {o }}$ As normas definidoras dos direitos e garantias fundamentais têm aplicação imediata. [...]

Art. 102. Compete ao Supremo Tribunal Federal, precipuamente, a guarda da Constituição, cabendo-lhe:

I - processar e julgar, originariamente: [...]

q) o mandado de injunção, quando a elaboração da norma regulamentadora for atribuição do Presidente da República, do Congresso Nacional, da Câmara dos Deputados, do Senado Federal, das Mesas de uma dessas Casas Legislativas, do Tribunal de Contas da União, de um dos Tribunais Superiores, ou do próprio Supremo Tribunal Federal;

II - julgar, em recurso ordinário:

a) o "habeas-corpus", o mandado de segurança, o "habeas-data" e o mandado de injunção decididos em única instância pelos Tribunais Superiores, se denegatória a decisão; [...]

Art. 105. Compete ao Superior Tribunal de Justiça:

I - processar e julgar, originariamente: [...]

h) o mandado de injunção, quando a elaboração da norma regulamentadora for atribuição de órgão, entidade ou autoridade federal, da administração direta ou indireta, excetuados os casos de competência do Supremo Tribunal Federal e dos órgãos da Justiça Militar, da Justiça Eleitoral, da Justiça do Trabalho e da Justiça Federal; [...]

Art. 121. Lei complementar disporá sobre a organização e competência dos tribunais, dos juízes e das juntas eleitorais. [...]

$\S 4^{\circ}$ Das decisões dos Tribunais Regionais Eleitorais somente caberá recurso quando: [...]

V - denegarem "habeas-corpus", mandado de segurança, "habeas-data" ou 
mandado de injunção. ${ }^{38}$

Os dispositivos transcritos foram incorporados à Constituição de 1988 nos artigos de numeração correspondente, ressalvado o artigo $4^{\circ}$, inciso LXXI e $\S 1^{\circ}$, do Projeto $C$, que corresponde ao artigo $5^{\circ}$, inciso LXXI e $\S 1^{\circ}$, do texto em vigor.

\section{AVALIAÇÃo ACERCA DAS CARACTERÍSTICAS ATRIBUÍDAS PELA CONSTITUINTE AO MANDADO DE INJUNÇÃO}

A reconstrução da trajetória seguida, durante o processo constituinte, pelas propostas relacionadas ao mandado de injunção, além de revelar as características que se pretendeu conferir ao instituto, explicita a extrema relevância que lhe era atribuída pelos membros da Assembleia Constituinte de 1987-1988.

Desde as primeiras sugestões apresentadas em favor da criação do mandado de injunção, esse instituto foi, reiteradamente, defendido com entusiasmo pelos constituintes que pretendiam sua positivação constitucional. Em diversos pronunciamentos realizados durante reuniões promovidas pelos órgãos da Assembleia, a instituição de instrumentos destinados a combater o problema da inconstitucionalidade por omissão e, em especial, do mandado de injunção foi considerada como sendo, senão o principal, um dos mais importantes avanços a serem propiciados pela Constituição que se tinha em perspectiva. Esse entusiasmo foi retratado, inclusive, no discurso proferido por Ulysses Guimarães por ocasião da promulgação da Constituição de 1988, em que o mandado de injunção foi um dos únicos institutos especificamente destacados pelo presidente da Assembleia, que o anunciou como sendo um instrumento de exercício da cidadania, capaz de propiciar provimentos suplementares nos casos de ausência de lei. ${ }^{39}$

${ }^{38}$ BRASIL, ASSEMBLEIA NACIONAL CONSTITUINTE. Projeto de Constituição (C): redação final [da Comissão de Redação], p. 4-70. Disponível em:

$<$ http://www.camara.gov.br/internet/constituicao20anos/DocumentosAvulsos/vol314.pdf>. Acesso em: 01 ago. 2016.

${ }^{39}$ BRASIL, ASSEMBLEIA NACIONAL CONSTITUINTE. Íntegra do discurso [do] Presidente da Assembléia Nacional Constituinte, Dr. Ulysses Guimarães (10'23"). Disponível em: $<$ http://www2.camara.leg.br/camaranoticias/radio/materias/CAMARAE-HISTORIA/339277--INTEGRA-DO-DISCURSO-PRESIDENTE-DA-ASSEMBLEIANACIONAL-CONSTITUINTE,--DR.-ULISSES-GUIMARAES-(10-23).html>. Acesso 
Anteriormente, em fevereiro de 1988, Ulysses Guimarães já havia declarado que “[...] 'o progresso extraordinário' da nova Carta pode ser medido pela aprovação do mandado de segurança coletivo, do mandado de injunção e do 'habeas data'." 40 .

A percepção, pelos constituintes, da importância do mandado de injunção e das consequências que poderiam advir de sua utilização também é depreendida das disputas travadas em torno da criação e da conformação a ser dada ao instituto. Diversamente do que sustentou o senador Alfredo Campos $^{41}$, em cujo entendimento o mandado de injunção fora aceito, pela quase unanimidade, como um dos grandes avanços da Constituinte, a positivação do instituto no texto constitucional não ocorreu de forma consensual, mas sofreu reiterada e veemente oposição por constituintes que representavam os interesses de entidades e grupos sociais liberais e conservadores. Revela-se mais acertada, portanto, a afirmação de José Egreja ${ }^{42}$, segundo o qual o mandado de injunção fora objeto de polêmica desde o início dos trabalhos da Constituinte. De fato, várias foram as tentativas de eliminação ou limitação do mandado de injunção, as quais ocorreram desde a fase de apresentação de emendas nas subcomissões temáticas até o segundo turno de discussão e votação, em Plenário, do Projeto de Constituição.

É verdade que a redação que restou positivada no artigo $5^{\circ}$, inciso LXXI, da Constituição foi aprovada, em primeiro turno de votação em Plenário, com 424 votos favoráveis e nenhum contrário. No entanto, a ausência de votos desfavoráveis nesse escrutínio não significa que a criação do mandado de injunção tenha sido aceita sem resistência na Constituinte, nem mesmo que as resistências houvessem sido superadas. Essa votação expressiva ocorreu em 10/2/1988, quando foram aprovados os já mencionados Destaques 1.250, 1.503 e 1.523, em decorrência de

em: 01 de agosto de 2016.

${ }^{40}$ ULYSSES pede na TV presença dos Constituintes. O Globo, Rio de Janeiro, p. 3, 20 fev. 1988. Disponível em: <http://www2.senado.leg.br/bdsf/item/id/125479>. Acesso em: 01 de agosto de 2016.

${ }^{41}$ BRASIL, ASSEMBLEIA NACIONAL CONSTITUINTE. Diário da Assembleia Nacional Constituinte, Brasília, 24 ago. 1988, p. 29. 1988. Disponível em: $<$ http://www.senado.leg.br/publicacoes/anais/constituinte/N023.pdf $>$. Acesso em: 01 de agosto de 2016. ${ }^{42}$ BRASIL, ASSEMBLEIA NACIONAL CONSTITUINTE. Diário da Assembleia Nacional Constituinte, Brasília, 10 ago. 1988, p. 177. Disponível em: $<$ http://www.senado.gov.br/publicacoes/anais/constituinte/N022.pdf $>$. Acesso em: 01 de agosto de 2016. 
acordo pontual firmado entre as lideranças. Nessa mesma data, o Centrão entrou em acordo com os partidos de esquerda e com o grupo progressista liderado pelo senador Mário Covas (PMDB) para a aprovação, também em primeiro turno, de vários outros dispositivos ensejadores de acirradas divergências na Constituinte, tais como as previsões relativas ao instituto do habeas data e aos direitos constitucionais de propriedade, de reunião e do consumidor, os quais igualmente contaram com votos favoráveis da ampla maioria dos constituintes.

Além disso, a aprovação do mandado de injunção em primeiro turno foi sucedida, como já dito, por novas tentativas de supressão e limitação do instituto, à semelhança do que havia ocorrido nas etapas anteriores do processo constituinte. Já em segundo turno de discussão e votação em Plenário, o mandado de injunção passou a ser alvo declarado das investidas do Centrão e de entidades representativas do empresariado, tais como a Confederação Nacional da Indústria ${ }^{43}$, a União dos Empresários $^{44}$ e o Fórum Informal de Empresários ${ }^{45}$, que elegeram a limitação do instituto em exame como uma de suas 24 finalidades prioritárias para essa fase. De outro lado, a Central Única dos Trabalhadores ${ }^{46}$ considerava o mandado de injunção como um dos 10 principais pontos do projeto a serem mantidos, ao passo que o Partido dos Trabalhadores ${ }^{47}$ reputava a criação do instituto como uma conquista inegociável.

Assim, a manutenção, até o término do processo constituinte, do texto que havia sido aprovado em primeiro turno e que originou o artigo 5, inciso LXXI, da Constituição apresenta-se como uma derrota daqueles

${ }^{3}$ JURISTAS divergem sobre o Mandado de Injunção. Folha de São Paulo, São Paulo, p. A6, 9 jul. 1988. Disponível em: <http://www2.senado.leg.br/bdsf/item/id/121093>.

Acesso em: 01 de agosto de 2016.

${ }^{44}$ FEDERAÇÕES preparam 200 emendas supressivas: entidade quer "direitos" de fora. Jornal do Brasil, Rio de Janeiro, p. 2, 05 jul. 1988. Disponível em: $<$ http://www2.senado.leg.br/bdsf/item/id/120523 $>$. Acesso em: 01 de agosto de 2016.

${ }^{45}$ DI FONZO, Edson. O que os empresários não querem. Jornal da Tarde, São Paulo, p. 8, 28 jun. 1988. Disponível em: <http://www2.senado.leg.br/bdsf/item/id/119992>.

Acesso em: 01 de agosto de 2016.

${ }^{46}$ BALTHAZAR, Ricardo. CUT inicia campanha de mobilização para manter direitos sociais. Gazeta Mercantil, São Paulo, p. A9, 25 jul. 1988. Disponível em:

<http://www2.senado.leg.br/bdsf/bitstream/handle/id/121251/1988 18\%20a\%2025\%20d e\%20Julho 145e.pdf?sequence=1>. Acesso em: 01 de agosto de 2016.

${ }_{47}$ PT quer volta de cartaz com "traidores". Folha de São Paulo, São Paulo, p. A7, 11 jul. 1988. Disponível em: <http://www2.senado.leg.br/bdsf/item/id/121157>. Acesso em: 01 de agosto de 2016. 
grupos e entidades que o senador Fernando Henrique Cardoso denominou de "forças reacionárias". Esses grupos e entidades pretendiam, ainda, retirar do Projeto de Constituição o dispositivo que conferia aplicação imediata aos direitos e garantias fundamentais, dentre os quais se incluía o próprio mandado de injunção, em razão do receio que possuíam quanto às consequências possivelmente decorrentes da incidência dessas normas.

É nítida, outrossim, a vinculação mantida, nas diversas fases do processo constituinte, entre o mandado de injunção e o objetivo de assegurar a efetividade de direitos sociais. Concebido, originariamente, para a proteção específica do direito à educação, as primeiras sugestões pela criação do instituto mencionam esse direito em suas justificativas. Nas etapas que se seguiram, o mandado de injunção foi reiteradamente associado tanto ao direito à educação, como ao direito à saúde, além de ter sido defendido como um instrumento necessário à defesa dos direitos sociais em geral e, especificamente, dos direitos à habitação, ao saneamento básico, ao lazer, à previdência, à segurança, à participação do trabalhador nos lucros da empresa e ao salário mínimo capaz de atender às suas necessidades vitais básicas e às de sua família. Nota-se, portanto, que, embora seu objeto inclua a concretização de outras espécies de normas constitucionais, a criação do mandado de injunção foi motivada, especialmente, pela necessidade de atribuição aos jurisdicionados de um instrumento capaz de promover a aplicação efetiva de direitos sociais de caráter transversal, ou seja, que não se restringem a grupos ou organizações sociais específicos, mas que atravessam vários deles, sendo pertinentes aos cidadãos e à sociedade em geral ou, ao menos, a diversos segmentos que a compõem. O mandado de injunção deveria, assim, contribuir para a finalidade de reestruturação da sociedade por meio do texto constitucional.

Por fim, quanto às características normativas do instituto em exame, observa-se que o texto aprovado pela Constituinte não define, de modo expresso e exaustivo, as propriedades do mandado de injunção. O relator da Comissão de Sistematização, deputado Bernardo Cabral, expôs, em diversas ocasiões, sua preferência pela elaboração de um texto constitucional sintético, que não deveria dispor sobre matérias consideradas como de caráter infraconstitucional. Sob essa justificativa, Bernardo Cabral rejeitou diversas emendas que sugeriam a inserção, no Projeto da Comissão de Sistematização, de regramentos detalhados a respeito do mandado de injunção. Desse modo, a Constituição somente tratou do instituto em dispositivos que definem os órgãos competentes para julgá-lo e no artigo 5ㅜㅜ, inciso LXXI, que se limita a definir o objeto do mandado de injunção e as espécies de preceitos constitucionais cujo 
descumprimento autoriza sua impetração. Não obstante a ausência de disposições expressas acerca de alguns de seus aspectos fundamentais, os trabalhos desenvolvidos pela Constituinte oferecem elementos que indicam as características que se pretendeu conferir ao instituto.

Verifica-se, primeiramente, que a Constituinte optou, ao final, por não condicionar a aplicação do mandado de injunção à prévia edição de lei que o regulamentasse. Em suas formulações iniciais, o mandado de injunção deveria se submeter ao rito processual estabelecido para o mandado de segurança. Posteriormente, a extensão do rito do mandado de segurança foi substituída pela necessidade de edição de lei complementar que disciplinasse a matéria. Como visto, essa modificação derivou do acolhimento, no Segundo Substitutivo do relator Bernardo Cabral, de emenda oferecida por Manoel Moreira, o qual, além de utilizar a justificativa de que se tratava de matéria infraconstitucional, deixou manifesta sua pretensão de protelar a aplicação do mandado de injunção, por considerar problemática a excessiva pressa na efetivação do instrumento. A estratégia de postergar a concretização das garantias fundamentais era utilizada, portanto, em relação ao próprio mandado de injunção. Na sequência, a previsão de lei complementar deu lugar à lei ordinária e, por fim, a menção à necessidade de edição de lei acerca do mandado de injunção foi suprimida do texto do projeto. Isso ocorreu, como visto, em 10/2/1988, data da aprovação dos Destaques 1.250, 1.503 e 1.523. Conforme assevera Marcelo Casseb Continentino ${ }^{48}$, "essa significativa modificação na estrutura normativa do mandado de injunção, portanto, decorreu da atitude deliberada de subtrair dessa garantia constitucional qualquer condicionamento de sua efetividade à eventual e incerta intermediação legislativa superveniente".

Ademais, o mandado de injunção foi criado como um instrumento processual de controle difuso e subjetivo da inconstitucionalidade por omissão. ${ }^{49}$ Além dos artigos 102, inciso I, alínea " $\mathrm{q}$ ", e inciso II, alínea "a"; 105, inciso $\mathrm{I}$, alínea " $\mathrm{h}$ "; e 121, $\S 4^{\mathrm{o}}$, inciso V, da Constituição, que distribuem a competência para julgá-lo a vários órgãos jurisdicionais, ao invés de concentrá-la no Supremo Tribunal Federal, o caráter difuso e subjetivo desse instrumento também é indiciado pelo fato de ter sido

${ }^{48}$ CONTINENTINO, Marcelo Casseb. Uma reflexão histórica sobre o Mandado de Injunção e a eficácia subjetiva das decisões. In: Gilmar Ferreira Mendes; André Rufino do Vale; Fábio Lima Quintas (Orgs.). Mandado de Injunção: estudos sobre sua regulamentação. São Paulo: Saraiva, 2013, p. 85.

${ }^{49}$ HAGE SOBRINHO, Jorge. Omissão Inconstitucional e Direito Subjetivo: uma apreciação da jurisprudência do STF sobre o Mandado de Injunção, à luz da doutrina contemporânea. Brasília, DF: Brasília Jurídica, 1999. 
inserido no Capítulo I do Título II da Constituição, que contempla direitos e garantias fundamentais dos indivíduos e do qual a ação direta por omissão acabou sendo excluída. Esse capítulo inclui, igualmente, o mandado de segurança, que também se reveste de caráter difuso e subjetivo e que constituiu uma das fontes de inspiração para o mandado de injunção $0^{50}$, conforme se depreende da própria denominação dada ao instituto em exame e da assimilação estabelecida entre ambos durante os trabalhos da Constituinte. Note-se, outrossim, que esse caráter difuso e subjetivo marcou o mandado de injunção do começo ao fim do processo constituinte, tendo sido destacado, por exemplo, nas sugestões iniciais de Virgílio Távora e Carlos Virgílio, assim como no discurso proferido por Nelson Jobim em 9/8/1988, ocasião em que o Plenário confirmou, em segundo turno, o texto do dispositivo que se converteria no artigo $5^{\circ}$, inciso LXXI, da Constituição.

Quanto aos efeitos produzidos pelo julgamento de procedência do mandado de injunção, os dispositivos constitucionais relacionados ao instituto não estabelecem disciplina normativa clara. Há, no entanto, diversos indícios que revelam a decisão prevalecente no âmbito da Assembleia Constituinte a respeito do assunto. Dentre esses vestígios, observa-se, em primeiro lugar, a mencionada assimilação entre mandado de injunção e mandado de segurança, seja pela designação atribuída aos institutos, seja pela pretensão inicial de estender o rito processual deste instrumento àquele que estava sendo criado. A aproximação feita entre os dois institutos não era fortuita, mas consentânea com o objetivo de estabelecer, para os casos de inconstitucionalidade por omissão, um instrumento processual tão eficaz quanto o mandado de segurança havia se revelado para a defesa do cidadão diante de ilegalidades ou abusos de poder praticados pelas autoridades públicas. A ideia, portanto, era a de criar um instrumento de caráter mandatório, capaz de resolver imediatamente as situações de ameaça ou violação a direitos, liberdades ou prerrogativas constitucionais em decorrência de omissão inconstitucional.

A denominação escolhida para o instituto não constitui fator de menor importância na investigação acerca dos efeitos produzidos pelo mandado de injunção. De fato, a persistente disputa travada em torno do nome a ser conferido ao instituto sugere que, para os constituintes, a definição das propriedades atribuídas ao mandado de injunção deveria ser

${ }^{50}$ OLIVEIRA, Herzeleide Maria Fernandes de. O Mandado de Injunção. Revista de Informação Legislativa, Ano 25, n. 100, 1988. 
consistente com a escolha de sua designação. ${ }^{51}$ A vinculação entre o nome e os efeitos do instituto manifestou-se, com nitidez, nas Emendas 29.346, 29.349 e 32.184, oferecidas pelo deputado José Egreja ao Primeiro Substitutivo do relator Bernardo Cabral, que sugeriam substituir o nome de "mandado de injunção" por "ação declaratória" e, consequentemente, transformá-lo em instrumento de eficácia meramente declaratória. Prevaleceu, entretanto, a designação original, que enfatiza, nos dois substantivos que a compõem, o caráter de ordem ou determinação a ser obrigatoriamente cumprida pela autoridade impetrada.

Essa percepção é reforçada, ainda, pelos debates realizados a respeito do instituto em primeiro e segundo turnos de discussão e votação em Plenário. Esses debates revelam que a redação finalmente conferida ao artigo 5º, inciso LXXI, da Constituição derivou do acatamento, em primeiro turno, de emendas que pretendiam resgatar a amplitude atribuída ao mandado de injunção em suas formulações iniciais, bem como do não acolhimento, em segundo turno, de emendas que se voltavam a limitar seu objeto ou a retirar-lhe o caráter de instrumento de controle da omissão inconstitucional. $\mathrm{Na}$ última discussão relatada a respeito do tema, ocorrida em 9/8/1988, quando foram descartados os destaques tendentes a modificar o mandado de injunção em segundo turno, prevaleceram os posicionamentos defendidos por Bernardo Cabral, que caracterizou o instituto como uma das mais importantes inovações da Constituinte, e por Nelson Jobim, que deixou clara a capacidade do mandado de injunção para viabilizar, de forma individual e independente do processo legislativo, a concretização dos direitos constitucionais. Em outros termos, a decisão definitiva da Assembleia Constituinte acerca do mandado de injunção baseou-se na concepção de que o instituto seria capaz de assegurar a aplicação das normas constitucionais dependentes de regulamentação de maneira imediata, ou seja, independentemente da intermediação do legislador.

O exame comparativo das decisões tomadas pela Constituinte a respeito do mandado de injunção e da ação direta de inconstitucionalidade por omissão também robustece essa constatação. Na Comissão de Sistematização e em Plenário, ambos os institutos foram objetos de emendas que sugeriam a limitação dos efeitos a serem produzidos por suas decisões, sob a justificativa de que a possibilidade de o Poder Judiciário concretizar, diretamente, as normas constitucionais

51 CONTINENTINO, Marcelo Casseb. Uma reflexão histórica sobre o Mandado de Injunção e a eficácia subjetiva das decisões. In: Gilmar Ferreira Mendes; André Rufino do Vale; Fábio Lima Quintas (Orgs.). Mandado de Injunção: estudos sobre sua regulamentação. São Paulo: Saraiva, 2013. 
dependentes de regulamentação afrontaria a tradição da sociedade brasileira e o princípio da separação de Poderes, segundo o qual o Judiciário deveria ser inerte e o Legislativo seria o titular do direito de legislar. Essa argumentação tipicamente liberal-conservadora, que confere a certas concepções jurídicas a aparência de que integrariam uma espécie de patrimônio institucional comum e indiscutível da humanidade, de modo que constituiriam limites ao exercício do próprio poder constituinte originário ${ }^{52}$, foi acolhida pela Constituinte quanto à ação direta por omissão, cuja eficácia se restringiu à mera declaração da omissão verificada e à cientificação do órgão legislativo omisso. Já quanto ao mandado de injunção, a decisão efetuada pelo Plenário da Constituinte foi diversa: a ofensiva articulada, em segundo turno, pelo Centrão e pelas entidades representativas do empresariado restou frustrada, tendo prevalecido, como visto, a proposta de resgatar, em sua integridade, a amplitude conferida ao mandado de injunção em suas formulações iniciais.

Assim, embora a Constituição não contenha previsão explícita quanto ao assunto, o processo constituinte oferece diversos indícios de que o mandado de injunção foi criado como um instrumento capaz de propiciar, diretamente, a concretização das normas constitucionais que careçam de regulamentação normativa. Essa compreensão é partilhada, por exemplo, por José Afonso da Silva, que, além de ter sido membro da "Comissão Afonso Arinos", participou da Constituinte na condição de assessor do senador Mário Covas. ${ }^{53}$ De acordo com referido constitucionalista, "todo o pensamento constituinte foi no sentido de estruturar um instrumento para assegurar imediatamente os direitos, liberdades e prerrogativas na falta de regulamentação" ${ }^{54}$, de modo que a decisão proferida em mandado de injunção deveria outorgar, de forma direta e imperativa, o direito reclamado.

52 GARGARELLA, Roberto. Pensando sobre la reforma constitucional en América Latina. In: César Rodríguez Garavito (Coord.). El derecho en América Latina: un mapa para el pensamiento jurídico del siglo XXI. Buenos Aires: Siglo Veintiuno, 2011. ${ }^{53}$ LÉLLIS, Leonardo. Todo conservador quer uma Constituição enxuta. Consultor Jurídico, São Paulo, 13 out. 2013. Disponível em: $<$ http://www.conjur.com.br/2013-out13/entrevista-jose-afonso-silva-jurista-doutrinador-constitucionalista\#author $>$. Acesso em: 01 de agosto de 2016.

${ }^{54}$ SILVA, José Afonso da. O Constitucionalismo Brasileiro: Evolução Institucional. São Paulo, SP: Malheiros, 2011. 


\section{CONSIDERAÇÕES FINAIS}

A Assembleia Nacional Constituinte de 1987-1988, ao instituir o mandado de injunção, optou por não estipular disciplina exaustiva acerca do instituto, tendo se limitado a definir seu objeto, as espécies de normas constitucionais cujo descumprimento enseja sua impetração e os órgãos competentes para processá-lo e julgá-lo. Embora alguns posicionamentos, especialmente de Bernardo Cabral, situem essa indefinição como uma estratégia de evitar a constitucionalização de questões meramente processuais, a falta de uma definição mais clara também parece ter decorrido da acirrada controvérsia que envolveu a aprovação do instituto. Se a mera aprovação dessa garantia constitucional dependia da superação de uma oposição incisiva e coordenada, a estipulação de um rito processual que lhe conferisse maior efetividade certamente enfrentaria ainda mais dificuldade, tendo em vista que parece ter sido uma das estratégias da oposição o deslocamento das questões processuais para a legislação específica, que poderia definir critérios que viessem a esvaziar substancialmente o instituto.

Essa estratégia foi, inclusive, vitoriosa durante muitos anos, tendo em vista que a edição de regras específicas sobre o mandado de injunção teve de aguardar mais de duas décadas e durante muito tempo foi mantida uma interpretação jurisprudencial que igualava os efeitos do mandado de injunção aos da ação direta de inconstitucionalidade por omissão. Tal restrição jurisprudencial colide com várias das posições adotadas pela Constituinte, conforme se depreende do conjunto de sugestões, emendas, decisões e debates verificados a respeito do mandado de injunção durante o processo constituinte, os quais servem de referência para a interpretação e aplicação do instrumento processual analisado e das regras legais editadas para reger sua utilização.

A análise dos registros produzidos pela Constituinte acerca do mandado de injunção deixa clara a importância atribuída ao instituto, seja para os constituintes favoráveis à sua criação, que o consideravam como uma das principais conquistas a serem propiciadas pela Constituição, seja por aqueles que a rejeitavam, dentre os quais se destacam os representantes de interesses de entidades liberais e conservadoras. Ambos os grupos de constituintes trataram a disputa em torno da instituição do mandado de injunção como uma questão prioritária, disputa essa que se encerrou com uma parcial vitória dos defensores do mandado de injunção, mas que durou pouco tempo em virtude da derrota sofrida pela interpretação por eles defendida no âmbito da política judiciária do STF. 
A devida consideração dos debates constituintes e dos atores envolvidos permite, inclusive, compreender melhor o significado do entendimento inicial do STF, que, após decidir que os mandados de injunção permaneceriam parados à espera de lei do Congresso Nacional, adotou entendimento jurisprudencial tendente a restringir a efetividade e a relevância prática desse instituto. Assim, além de terem buscado influir nas decisões da Constituinte por meio, inclusive, de alianças com parlamentares conservadores, os ministros do STF prorrogaram, na esfera judicial, a disputa política travada entre os constituintes a respeito dos efeitos e da aplicabilidade do mandado de injunção, possibilitando a reversão jurisprudencial de parcela das derrotas sofridas durante o processo constituinte. Para sustentar seu entendimento, o STF utilizou-se, inadequada e seletivamente, de argumentos sustentados pelos constituintes que se opuseram à criação do mandado de injunção e que somente prevaleceram, no âmbito da Constituinte quanto à direta ação de inconstitucionalidade por omissão, tendo sido rejeitados quanto ao mandado de injunção.

Mesmo com a posterior mudança na jurisprudência da Corte, que veio a atribuir uma eficácia mais ampla ao mandado de injunção, não se pode atestar que os objetivos que motivaram a introdução desse instituto tenham sido alcançados, visto que, em exame preliminar ao conjunto de acórdãos proferidos em sede de mandado de injunção, se constata que os diretos efetivamente tutelados pelo STF desde 1988, além de serem pouco numerosos, dificilmente podem ser caracterizados como direitos sociais de caráter transversal. Tem-se, pois, indícios da baixa efetividade do mandado de injunção, os quais necessitam de pesquisa empírica exaustiva acerca dos processos dessa espécie impetrados perante o STF para que sejam confirmados, de modo a confrontar as finalidades perseguidas pelos constituintes que sustentaram a criação do instituto com os resultados práticos de sua utilização pelos jurisdicionados

De fato, a relevância do mandado de injunção para os próprios constituintes relacionava-se à sua vinculação, observada desde as formulações originárias propostas para o instituto, com o dever estatal de concretizar os direitos sociais formalmente assegurados pela Constituição aos jurisdicionados em geral. A expectativa dos defensores da criação do mandado de injunção era a de que referido instituto fosse capaz de contribuir para a ocorrência de efetiva reestruturação da sociedade brasileira por meio da Constituição de 1988. A análise dos discursos legislativos envolvidos no processo de aprovação desse texto indica que o mandado de injunção foi instituído pela Constituinte para assegurar a aplicação das normas constitucionais dependentes de regulamentação de maneira imediata, ou seja, independentemente da intermediação do 
legislador, tendo sido rejeitada proposta tendente a transformá-lo em instrumento processual de eficácia meramente declaratória.

Por fim, nota-se que a disputa travada a respeito do mandado de injunção não findou com o encerramento dos trabalhos da Constituinte. Embora se cuide de tema que demanda trabalho posterior, a leitura do teor da Lei 13.300/16 revela que esse ato legislativo, além de consolidar entendimentos adotados pela jurisprudência do STF, torna explícitas algumas das características atribuídas ao mandado de injunção pela Assembleia Constituinte, tais como: a vinculação entre o instituto em exame e o mandado de segurança; o especial objetivo de viabilizar o exercício dos direitos sociais, o qual é reforçado pela possibilidade de impetração de mandado de injunção coletivo pelo Ministério Público, pela Defensoria Pública e pelos partidos políticos; e a autorização conferida ao Poder Judiciário para fixar prazo para que o impetrado promova a edição da norma regulamentadora, bem como para estabelecer as condições em que se dará o exercício dos direitos, das liberdades ou das prerrogativas reclamados, caso não seja suprida a omissão no prazo estipulado. Em outros termos, a edição da lei mencionada confere novo estímulo à disputa mencionada e propicia um retorno ao momento de criação do instituto, seja para confrontar os textos normativos produzidos nesses dois momentos, seja para extrair, do processo constituinte, diretrizes para a interpretação e aplicação do novel diploma normativo.

\section{REFERÊNCIAS}

ARAÚJO, Luiz Henrique Diniz. O Mandado de Segurança, o Mandado de Injunção e a efetivação dos direitos sociais. Revista de Informação Legislativa, Ano 50, n. 199, 2013.

BALTHAZAR, Ricardo. CUT inicia campanha de mobilização para manter direitos sociais. Gazeta Mercantil, São Paulo, p. A9, 25 jul. 1988. Disponível em:

$<$ http://www2.senado.leg.br/bdsf/bitstream/handle/id/121251/1988 18\% 20a\%2025\%20de\%20|ulho 145e.pdf?sequence=1>. Acesso em: $01 \mathrm{de}$ agosto de 2016. 
BRASIL, ASSEMBLÉIA NACIONAL CONSTITUINTE. Anteprojeto [da Subcomissão dos Direitos e Garantias Individuais]. Disponível em: $<$ http://www.camara.gov.br/internet/constituicao20anos/DocumentosAv ulsos/vol-81.pdf $>$. Acesso em: 01 de agosto de 2016.

. Anteprojeto [da Subcomissão dos Direitos Políticos, dos

Direitos Coletivos e Garantias]. Disponível em:

$<$ http://www.camara.gov.br/internet/constituicao20anos/DocumentosAv ulsos/vol-77.pdf $>$. Acesso em: 01 de agosto de 2016.

. Anteprojeto de Constituição [da Comissão de Sistematização].

Disponível em:

$<$ http://www.camara.gov.br/internet/constituicao20anos/DocumentosAv ulsos/vol-219.pdf >. Acesso em: 01 de agosto de 2016.

. Diário da Assembleia Nacional Constituinte, Brasília, 11 fev. 1988, p. 510. Disponível em:

$\langle$ http://www.senado.leg.br/publicacoes/anais/constituinte/N012.pdf $>$. Acesso em: 01 de agosto de 2016.

. Diário da Assembleia Nacional Constituinte, Brasília, 29 abr. 1987, Suplemento, p. 69-111. Disponível em: $<$ http://www2.camara.leg.br/atividadelegislativa/legislacao/Constituicoes Brasileiras/constituicao-cidada/oprocesso-constituinte/sugestoes-dos-constituintes/arquivos/SGCO01010200.pdf >. Acesso em: 01 de agosto de 2016.

. Diário da Assembleia Nacional Constituinte, Brasília, 29 abr. 1987, Suplemento, p. 137-169. Disponível em:

$<$ http://www2.camara.leg.br/atividade-

legislativa/legislacao/Constituicoes Brasileiras/constituicao-cidada/oprocesso-constituinte/sugestoes-dos-constituintes/arquivos/sgco03010400>. Acesso em: 01 de agosto de 2016. 
. Diário da Assembleia Nacional Constituinte, Brasília, 10 ago. 1988, p. 177. Disponível em:

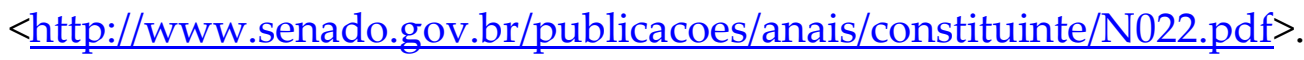
Acesso em: 01 de agosto de 2016.

. Diário da Assembleia Nacional Constituinte, Brasília, 24 ago. 1988, p. 29. 1988. Disponível em:

$<$ http://www.senado.leg.br/publicacoes/anais/constituinte/N023.pdf $>$. Acesso em: 01 de agosto de 2016.

. Íntegra do discurso [do] Presidente da Assembléia Nacional Constituinte, Dr. Ulysses Guimarães (10'23"). Disponível em: $<$ http://www2.camara.leg.br/camaranoticias/radio/materias/CAMARAE-HISTORIA/339277--INTEGRA-DO-DISCURSO-PRESIDENTE-DAASSEMBLEIA-NACIONAL-CONSTITUINTE,--DR.-ULISSESGUIMARAES-(10-23).html>. Acesso em: 01 de agosto de 2016.

. Parecer e Substitutivo [do Relator da Comissão da Soberania e dos Direitos e Garantias do Homem e da Mulher]. Disponível em: $<$ http://www.camara.gov.br/internet/constituicao20anos/DocumentosAv ulsos/vol-68.pdf $>$. Acesso em: 01 de agosto de 2016.

. Primeiro Substitutivo do Relator e Parecer [da Comissão de Sistematização ao Projeto de Constituição]. Disponível em: $<$ http://www.camara.gov.br/internet/constituicao20anos/DocumentosAv ulsos/vol-235.pdf >. Acesso em: 01 de agosto de 2016.

. Projeto de Constituição (A) [da Comissão de Sistematização].

Disponível em:

$<$ http://www.camara.gov.br/internet/constituicao20anos/DocumentosAv ulsos/vol-251.pdf>. Acesso em: 01 de agosto de 2016. 
. Projeto de Constituição (C): redação final [da Comissão de Redação]. Disponível em:

$<$ http://www.camara.gov.br/internet/constituicao20anos/DocumentosAv ulsos/vol-314.pdf $>$. Acesso em: 01 ago. 2016.

. Projeto de Constituição: Emendas Oferecidas em Plenário ao Substitutivo do Relator, Vol. III (Emendas 27037 a 31127), p. 2203.

Disponível em: $<$ http://www.camara.gov.br/internet/constituicao20anos/DocumentosAv ulsos/vol-238.pdf > . Acesso em: 01 de agosto de 2016.

. Projeto de Constituição: redação para o segundo turno de discussão e votação, p. 18. Disponível em: $<$ http://www.camara.gov.br/internet/constituicao20anos/DocumentosAv ulsos/vol-299-sup01.pdf >. Acesso em: 01 de agosto de 2016.

. Relatório e Anteprojeto [do Relator da Subcomissão dos

Direitos e Garantias Individuais]. Disponível em:

$<$ http://www.camara.gov.br/internet/constituicao20anos/DocumentosAv ulsos/vol-78.pdf $>$. Acesso em: 01 de agosto de 2016.

. Segundo Substitutivo do Relator [da Comissão de

Sistematização ao Projeto de Constituição]. Disponível em:

$<$ http://www.camara.gov.br/internet/constituicao20anos/DocumentosAv ulsos/vol-242.pdf $>$. Acesso em: 01 de agosto de 2016.

BRASIL, SUPREMO TRIBUNAL FEDERAL. Exposição de Motivos: inovações sugeridas pelo Supremo Tribunal Federal. Diário da Justiça, Brasília, ano 61, n. 131, p. 12289-12295, 14 jul. 1986. Disponível em: $<$ http://www.stf.jus.br/arquivo/biblioteca/PastaSTF/Curiosidades/1986 j ul 14.pdf $>$. Acesso em: 01 de agosto de 2016. 
CANOTILHO, José Joaquim Gomes. Constituição Dirigente e Vinculação do Legislador: contributo para a compreensão das normas constitucionais programáticas. Coimbra: Coimbra Editora, 1982.

CENTRO consegue 314 assinaturas para mudar regimento. Folha de São Paulo, São Paulo, p. A9, 11 nov. 1987. Disponível em: $<$ http://www2.senado.leg.br/bdsf/item/id/152808 $>$. Acesso em: $01 \mathrm{de}$ agosto de 2016.

CONTINENTINO, Marcelo Casseb. Uma reflexão histórica sobre o Mandado de Injunção e a eficácia subjetiva das decisões. In: Gilmar Ferreira Mendes; André Rufino do Vale; Fábio Lima Quintas (Orgs.). Mandado de Injunção: estudos sobre sua regulamentação. São Paulo: Saraiva, 2013.

DI FONZO, Edson. O que os empresários não querem. Jornal da Tarde, São Paulo, p. 8, 28 jun. 1988. Disponível em: $<$ http://www2.senado.leg.br/bdsf/item/id/119992>. Acesso em: 01 de agosto de 2016.

FEDERAÇÕES preparam 200 emendas supressivas: entidade quer "direitos" de fora. Jornal do Brasil, Rio de Janeiro, p. 2, 05 jul. 1988.

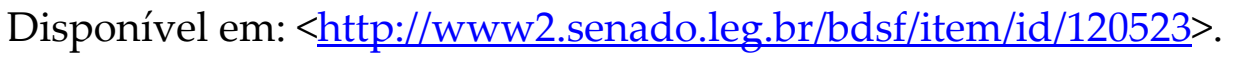
Acesso em: 01 de agosto de 2016.

GADAMER, Hans-Georg. Verdade e método: traços fundamentais de uma hermenêutica filosófica. Trad. Flávio Paulo Meurer. $3^{\underline{a}}$ ed. Petrópolis, RJ: Vozes, 1999.

GALLO, Luiz Carlos; FACHIN, Zulmar. O Mandado de Injunção na Jurisprudência do Supremo Tribunal Federal. Revista Jurídica Cesumar - Mestrado, Vol. 12, 1, 2012. 
GARGARELLA, Roberto. Pensando sobre la reforma constitucional en América Latina. In: César Rodríguez Garavito (Coord.). El derecho en América Latina: un mapa para el pensamiento jurídico del siglo XXI. Buenos Aires: Siglo Veintiuno, 2011.

HAGE SOBRINHO, Jorge. Omissão Inconstitucional e Direito Subjetivo: uma apreciação da jurisprudência do STF sobre o Mandado de Injunção, à luz da doutrina contemporânea. Brasília, DF: Brasília Jurídica, 1999.

JURISTAS divergem sobre o Mandado de Injunção. Folha de São Paulo, São Paulo, p. A6, 9 jul. 1988. Disponível em:

$<$ http://www2.senado.leg.br/bdsf/item/id/121093 $>$. Acesso em: 01 de agosto de 2016.

KOERNER, Andrei; FREITAS, Lígia Barros de. O Supremo na Constituinte e a Constituinte no Supremo. Lua Nova, No. 88, 2013. Disponível em: $<$ http://www.scielo.br/pdf/ln/n88/a06n88.pdf $>$. Acesso em: 01 de agosto de 2016.

LÉLLIS, Leonardo. Todo conservador quer uma Constituição enxuta. Consultor Jurídico, São Paulo, 13 out. 2013. Disponível em: $<$ http://www.conjur.com.br/2013-out-13/entrevista-jose-afonso-silvajurista-doutrinador-constitucionalista\#author>. Acesso em: 01 de agosto de 2016.

LIMA, Luziano Pereira Mendes de. A atuação da esquerda no processo constituinte: 1986-1988. Brasília, DF: Edições Câmara, 2009.

MENDES, Gilmar Ferreira. O mandado de injunção e a necessidade de sua regulação legislativa. Revista Jurídica da Presidência, Vol. 13, 100, 2011. 
OLIVEIRA, Herzeleide Maria Fernandes de. O Mandado de Injunção. Revista de Informação Legislativa, Ano 25, n. 100, 1988.

OLIVEIRA, Mauro Márcio. Fontes de informações sobre a Assembléia Nacional Constituinte de 1987: quais são, onde buscá-las e como usálas. Brasília, DF: Subsecretaria de Edições Técnicas do Senado Federal, 1993.

PT quer volta de cartaz com "traidores". Folha de São Paulo, São Paulo, p. A7, 11 jul. 1988. Disponível em:

$<$ http://www2.senado.leg.br/bdsf/item/id/121157>. Acesso em: 01 de agosto de 2016.

RAMOS, Elival da Silva. Mandado de injunção e separação dos Poderes. Cadernos Jurídicos, Ano 16, n. 40, 2015.

RAMOS, Paulo Roberto Barbosa; LIMA, Diogo Diniz. Mandado de injunção: origem e perspectivas. Revista de Informação Legislativa, Ano 48, n. 191, 2011.

ROTHENBURG, Walter Claudius. A segunda geração do mandado de injunção. Revista de Informação Legislativa, Ano 47, n. 188, 2010.

SILVA, José Afonso da. Aplicabilidade das Normas Constitucionais. $8^{a}$ ed. São Paulo, SP: Malheiros, 2012.

SILVA, José Afonso da. O Constitucionalismo Brasileiro: Evolução Institucional. São Paulo, SP: Malheiros, 2011.

ULYSSES pede na TV presença dos Constituintes. O Globo, Rio de Janeiro, p. 3, 20 fev. 1988. Disponível em:

$<$ http://www2.senado.leg.br/bdsf/item/id/125479>. Acesso em: 01 de agosto de 2016. 
O Mandado de Injunção na Assembleia Nacional Constituinte de 1987-1988 The Writ of Injunction in the National Constitutional Assembly of 1987-1988 Submetido em: 2016-09-21 Aceito em: 2017-01-30 